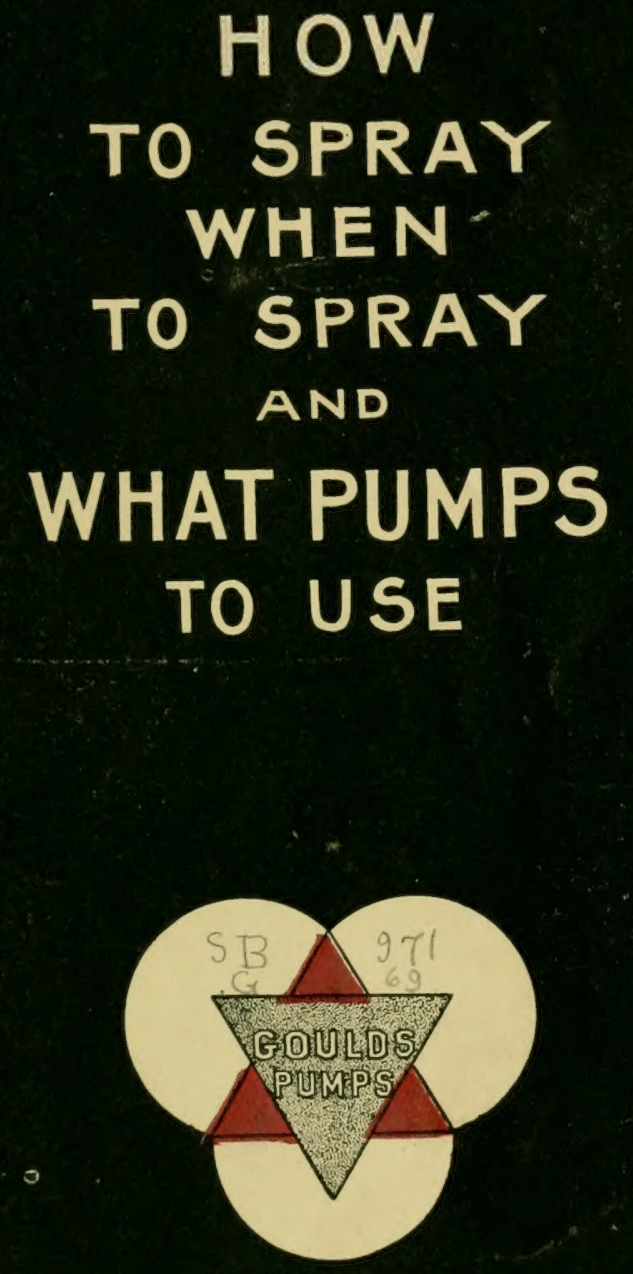




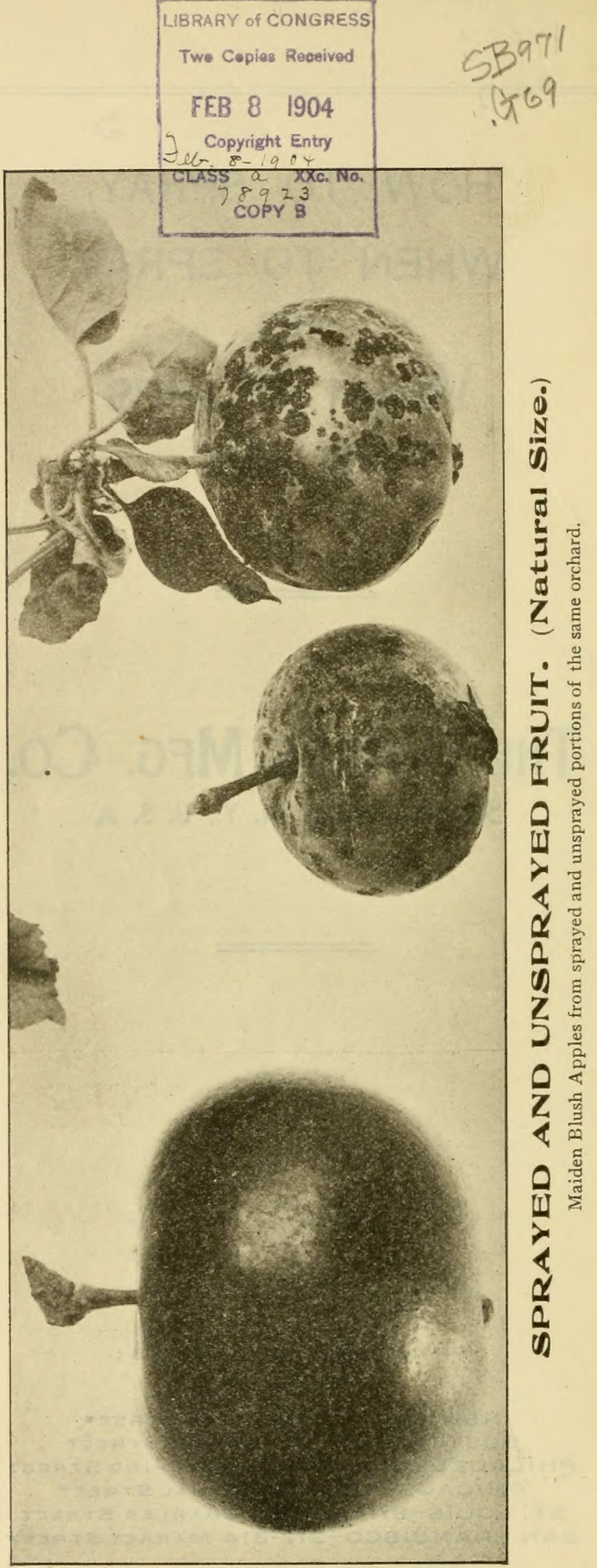




\section{How to Spray, When to Spray and What Pumps to use.}

Spraying is to fruit growers what insurance is to a merchant. While insurance protects the merchant from loss by fire, careful spraying not only protects from loss but assures good fruit and a profit to the grower. You cannot afford to go without this protection when it can be had so easily. It is not a good business policy. Ask the successful fruit grower what he thinks of spraying. It is true some have given up spraying saying " it does not pay," but after a season or so of "bad luck" as they call it, they again take up spraying rather than leave the trees to the mercy of the pests that are so numerous these days.

With each season new ideas are brought out which tend to improve and advance the methods of spraying. The LimeSulphur-Salt wash coming into more general use has brought about much discussion as to how this wash effects the different metals and other materials used in spraying. There seems to be a great difference of opinion as to the construction of the proper Pump. To satisfy ourselves and in order that we might have some positive knowledge on this important subject, we have made exhaustive Tests with this solution in connection with our Spraying Apparatus. The outcome of these tests shows conclusively that the wash does not materially effect either iron or brass parts, but at the same time we have learned some valuable points and have embodied them in our goods for this year. All Pumps and spraying Apparatus should be thoroughly cleaned after use, thereby prolonging their life materially.

When we brought out our "Monarch" Pump we carried out the idea of Vertical Outside Packed Plungers. This idea has proven to be a most remarkable one both as to durability and ease of operation. In the new "Sentinel Jr." which is equipped with removal bronze lining, we have solved the perplexing question which always faces the maker of Horizontal Cylinder Pumps.

The most remarkable idea advanced in years, however, is carried out in our new "Mistry" Nozzle, which while it resembles the "Vermorel" in appearances, gives a finer cloud of spray. This is accomplished at an exceedingly low pressure and makes the operation of Spray Pumps about -twice as easy as before.

We know that the ideas which we have carried out this year will meet with the general approval of the public, because they are what the public are asking for. As we have often remarked before, we are not practical fruit growers, but manufacturers of Pumps. All our most important results were originally suggested by fruit growers and have been perfected through our knowledge of Pump building. We are always glad to coöperate with the fruit growing public and carrying out any ideas which might prove beneficial to spraying.

The Goulds Manufacturing Co.

NotE-See Spray Calendar, pp. 34-37.

See Formulas, pp. 37-40. 


\section{Goulds "Pomona " Spray Pump.}

\section{With Agitator. A11 Working Parts Bronze.}

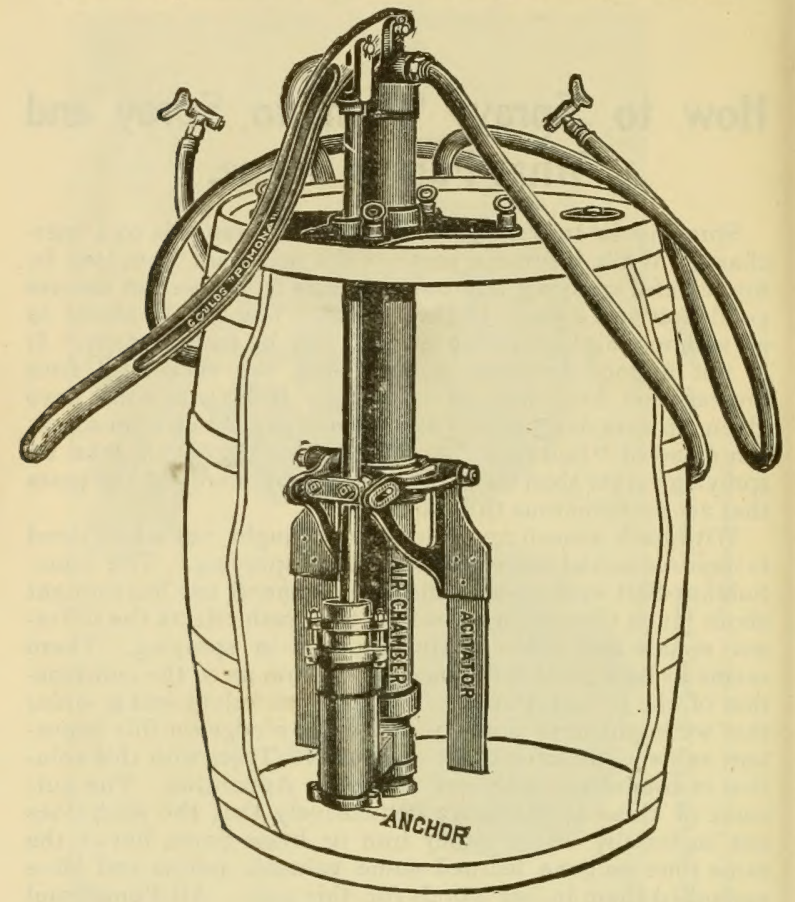

Fig. Iroo, "Pomona" Spray Pump, has great power and capacity. No leather packings. All working parts bronze, including plunger, gland, valves, valve seats, etc. Plunger is outside packed. Valves are easily accessible for examination. Air chamber of steel. Powerful level with adjustable stroke. Pump projects but little above top of barrel.

Pumps for side of barrel to order. No extra charge.

Pump, less agitator, deduct $\$ 1.00$ from list. We supply barrel and mount pump in same for $\$ 1.75$ extra net.

Fig. rroo. Pump, Equipment, Etc.

\begin{tabular}{|c|c|c|c|c|}
\hline & \multicolumn{2}{|c|}{ Plunger. } & \multirow{2}{*}{$\begin{array}{l}\text { Double } \\
\text { Discharge. }\end{array}$} & \multirow{2}{*}{$\begin{array}{l}\text { List } \\
\text { Price. }\end{array}$} \\
\hline & Diam. & Stroke. & & \\
\hline $\begin{array}{c}\text { Pump with Agita- } \\
\text { tor and } \\
\text { Hose Coupling. }\end{array}$ & $23 / 2 \mathrm{in}$. & $\begin{array}{l}\text { Adjust- } \\
\text { able } 3,4 \\
\text { or } 5 \text { in. }\end{array}$ & $\begin{array}{l}1 / 2 \text { in. hose and } \\
3 / 4 \text { in. pipe. }\end{array}$ & $\$ 15.00$ \\
\hline $\begin{array}{l}\text { Outfit C. } \\
\text { with One Lead } \\
\text { Discharge Hose } \\
\text { and Nozzle. }\end{array}$ & \multicolumn{3}{|c|}{$\begin{array}{l}\text { Fig. Iroo. Spray Pump with agita- } \\
\text { tor and one lead } 15 \text { feet } 1 / 2 \text {-inch dis- } \\
\text { charge hose with " Mistry" or "Seneca" } \\
\text { Spray Nozzle. }\end{array}$} & 18.75 \\
\hline $\begin{array}{l}\text { Outfit D. } \\
\text { with Two Leads } \\
\text { Discharge Hose } \\
\text { and Nozzles. }\end{array}$ & \multicolumn{3}{|c|}{$\begin{array}{l}\text { Fig. moo. Spray Pump with agita- } \\
\text { tor and two leads } 15 \text { feet each } 1 / 2 \text {-inch dis- } \\
\text { charge hose with "Mistry" or "Seneca" } \\
\text { Spray Nozzles. }\end{array}$} & 22.00 \\
\hline
\end{tabular}

For Extra Hose, Nozzles, Extensions, etc., see pages 28 to 33 . 


\section{Goulds "Savelot" Spray Pump.}

\section{With Agitator. All Working Parts Brass.}

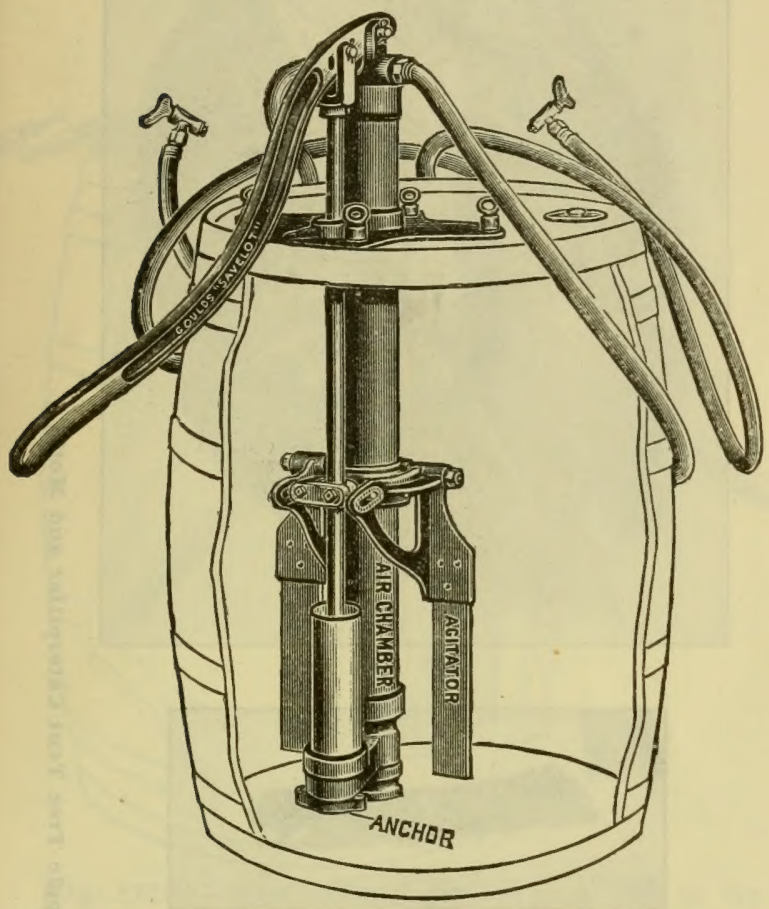

Fig. I336. "Savelot" differs from Fig. I100 "Pomona," only in having brass tube cylinder and brass piston, with cupped packings made of special material which is not affected or hardened by the chemicals used in spraying. No leather is used either on piston or valves. Valves are bronze on bronze seats and are easily accessible. Agitator of most effective type. Powerful lever with adjustable stroke. Pump projects but little above top of barrel. Pumps to order for side of barrel.

Pump less agitator deduct $\$ 1.00$ from list. We supply barrel and mount pump in same for \$1.75 extra net.

Fig. r336. Pump, Equipment, Etc.

\begin{tabular}{|c|c|c|c|c|}
\hline & \multicolumn{2}{|c|}{ Plunger. } & \multirow{2}{*}{$\begin{array}{c}\text { Double } \\
\text { Discharge. }\end{array}$} & \multirow{2}{*}{$\begin{array}{l}\text { List } \\
\text { Price. }\end{array}$} \\
\hline & Diam. & Stroke. & & \\
\hline $\begin{array}{l}\text { Pump with } \\
\text { Agitator and } \\
\text { Hose Coupling. }\end{array}$ & $2^{1 / 2}$ in. & $\begin{array}{l}\text { Adjustable } \\
3,4 \text { or } 5 \text { in. }\end{array}$ & $1 / 2$ in. hose. & $\$ 13.50$ \\
\hline $\begin{array}{l}\text { Outfit C. } \\
\text { with One Lead } \\
\text { Discharge Hose } \\
\text { and Nozzle. }\end{array}$ & \multicolumn{3}{|c|}{ 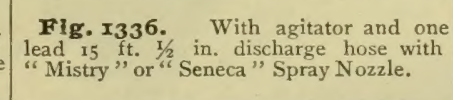 } & 17.30 \\
\hline $\begin{array}{l}\text { Outfit D. } \\
\text { with Two Leails } \\
\text { Discharge Hose } \\
\text { and Nozzle. }\end{array}$ & \multicolumn{3}{|c|}{$\begin{array}{l}\text { Fig. I336. With agitator and two } \\
\text { leads I5 ft. each, 1/2 in. discharge hose } \\
\text { with "Mistry" or "Seneca" Spray Noz- } \\
\text { zle. }\end{array}$} & 20.60 \\
\hline
\end{tabular}

For Extra Hose, Nozzles, Extension, etc, see pages 28 to 33 . 


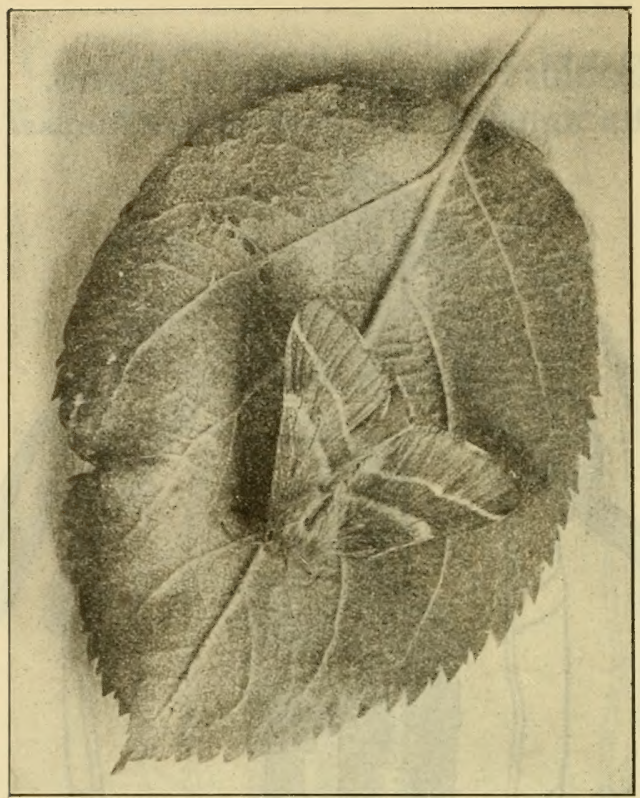



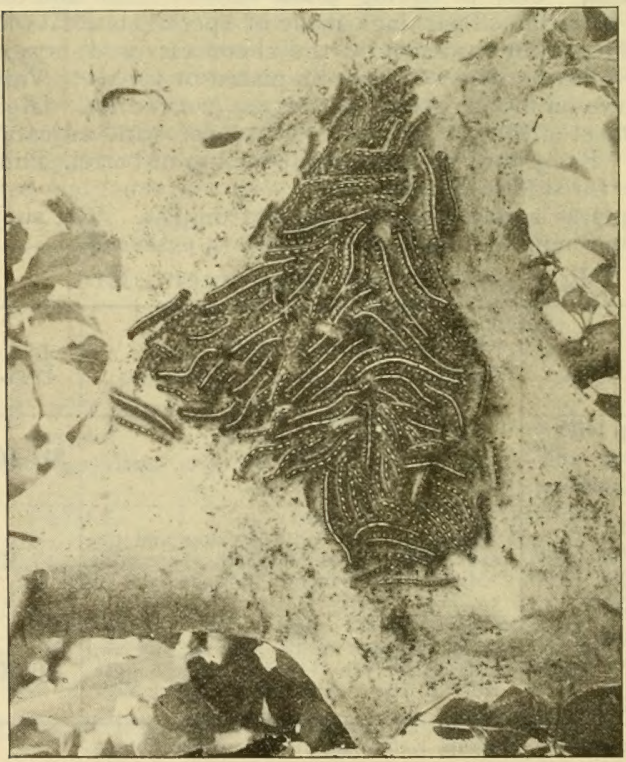




\section{Goulds "Standard" Spray Pump.}

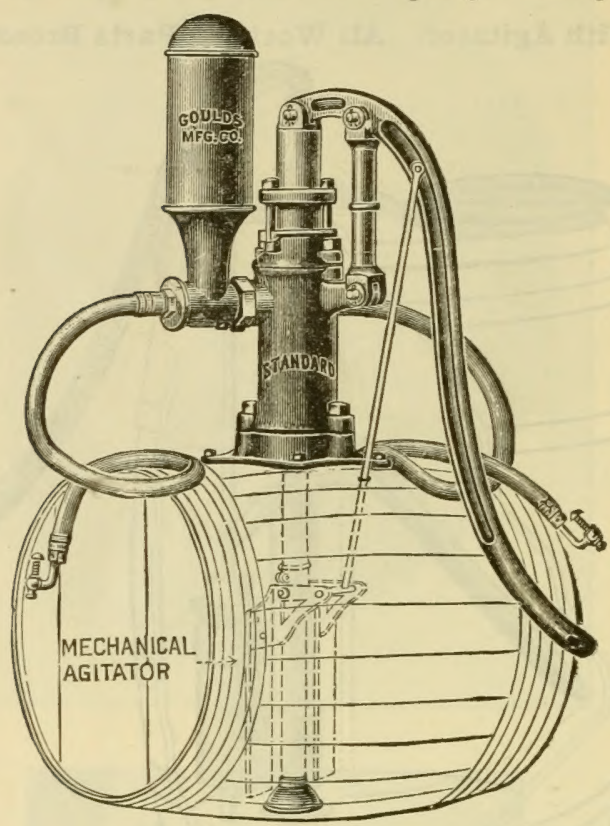

Fig. 905 $\frac{1}{2}$. With Brass-Lined Cylinder, Brass-Cased Plunger and Brass Valves.

Is the same as Fig. 905, described on preceding page, but has an additional air chamber on discharge.

Dash Agitator, Fig. I079, see outline on preceding page $\$ 1.25$ extra list.

Mechanical agitator, Fig. I321, see outline cut above, $\$ 1.50$ extra list.

Fig. 905 $\frac{1}{2}$. Pump, Equipment, Etc.

\begin{tabular}{|c|c|c|c|c|c|}
\hline & No. & $\begin{array}{l}\text { Dia. } \\
\text { Cyl. }\end{array}$ & Suction. & Double Dis. & $\begin{array}{l}\text { List } \\
\text { Price. }\end{array}$ \\
\hline $\begin{array}{l}\text { Pump with } \\
\text { Strainer. }\end{array}$ & $\begin{array}{l}2 \\
4\end{array}$ & $\begin{array}{l}2 y / 2 \text { in. } \\
3 \text { " }\end{array}$ & $\begin{array}{l}x \text { in. pipe. } \\
x^{x / 4} \text { " }\end{array}$ & $\begin{array}{l}3 / 2 \text { in. hose and } \\
3 / 4 \text { in. pipe. } \\
3 / 4 \text { in. hose and } \\
1 \text { in. pipe. }\end{array}$ & $\begin{array}{l}\$ 9.50 \\
10.50\end{array}$ \\
\hline $\begin{array}{l}\text { Outfit C. } \\
\text { with one } \\
\text { lead of hose } \\
\text { and nozzle. } \\
\text { Outfit CC. }\end{array}$ & $\begin{array}{l}\text { Fig. } \\
\text { iron } \mathrm{S} \\
\text { of } 15 \mathrm{ft} \\
\text { " Sene } \\
\text { Fig. } \\
\text { same n }\end{array}$ & $\begin{array}{l}905^{1 / 2} \\
\text { ction pi } \\
1 / 2 \text { in. d } \\
\text { a" Spra } \\
905^{1 / 2} \text {. } \\
\text { anner. }\end{array}$ & $\begin{array}{l}2 \frac{1}{2} \text { in. } \\
\text { brass str } \\
\text { charge hose, } \\
\text { Nozzle. } \\
3 \text { in. Spr }\end{array}$ & $\begin{array}{l}\text { pray Pump with } \\
\text { with "Mistry" or } \\
\text { " Mump fitted in }\end{array}$ & $\begin{array}{l}15.00 \\
16.00\end{array}$ \\
\hline $\begin{array}{l}\text { Outfit D. } \\
\text { with two } \\
\text { leads of hose } \\
\text { and nozzles. } \\
\text { Outfit DD. }\end{array}$ & $\begin{array}{l}\text { Fig. } \\
\text { suction } \\
\text { 15 ft. } \mathrm{e} \\
\text { or "Se } \\
\text { Fig. } \\
\text { same n }\end{array}$ & $\begin{array}{l}905^{1 / 2} . \\
\text { pipe, br } \\
\text { ch } 1 / 2, \mathrm{in} . \\
\text { eca " Sp } \\
905^{1 / 2} . \\
\text { anner. }\end{array}$ & $\begin{array}{l}1 / 2 \text { in. Spra } \\
\text { ss strainer } \\
\text { lischarge ho } \\
\text { ay Nozzles. } \\
3 \text { in. Spra }\end{array}$ & $\begin{array}{l}\text { Pump with iron } \\
\text { and two leads of } \\
\text { se, with "Mistry" } \\
\text { y Pump fitted in }\end{array}$ & $\begin{array}{l}19.50 \\
20.50\end{array}$ \\
\hline
\end{tabular}

For Extra Hose, Nozzles, Extensions, etc., see pages 28 to 33 . 


\section{Goulds "Standard" Spray Pump.}

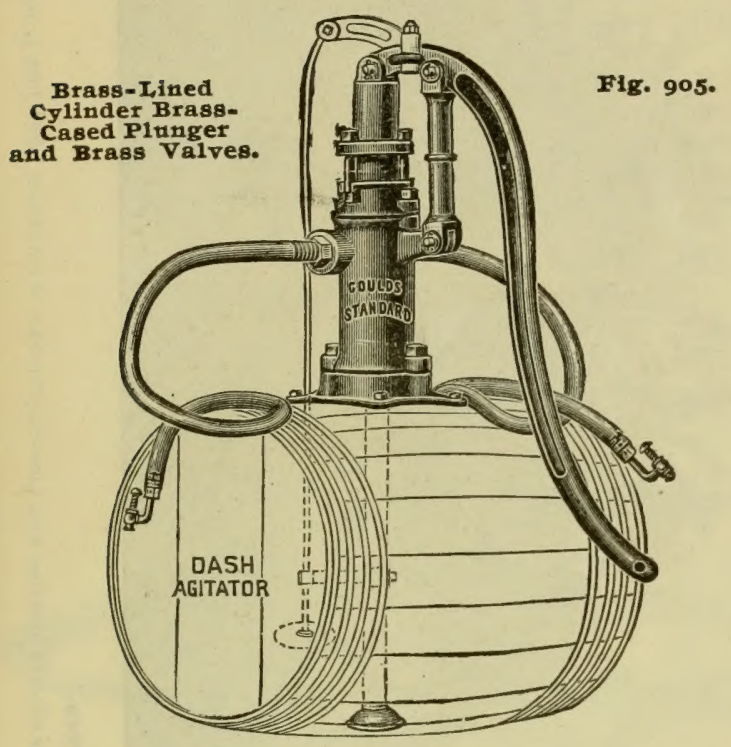

Fig. 905. "Standard" Spray Pump is Double-Acting in effect. The differential plunger forms the air chamber and contributes to sustaining a continuous and uniform discharge at spray nozzles. Has brass lower valve and seat with galvanized cage.

The base is adapted for either end or side of barrel. Pump has double discharge, one plugged, other fitted with hose coupling. Brass strainer supplied.

Dash Agitator, Fig. ro79, see outline cut above, \$I.25 extra list. Mechanical Agitator, Fig. I32I, see outline on opposite page, \$I.50 extra list.

Fig. 905. Pump, Equipment, Etc.

\begin{tabular}{|c|c|c|c|c|c|}
\hline & No. & Dia. Cyl. & Suction. & Double Dis. & \\
\hline 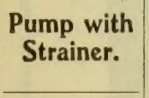 & $\begin{array}{l}2 \\
4\end{array}$ & $\begin{array}{ll}21 / 2 & \text { in. } \\
3 & \text { " }\end{array}$ & $\begin{array}{l}\mathrm{I} \text { in. pipe. } \\
\mathrm{I}^{1} / \mathrm{i} \text { in. pipe. }\end{array}$ & $\begin{array}{l}3 / 4 \text { in } \\
3 / 4 \text { in. } 1 \\
\mathrm{~J} \text { in. }\end{array}$ & $\begin{array}{r}\$ 8.50 \\
9.50\end{array}$ \\
\hline $\begin{array}{l}\text { Outfit C. } \\
\text { with one leaa } \\
\text { of hose and } \\
\text { nozzle. } \\
\text { Outfit CC. }\end{array}$ & \multicolumn{4}{|c|}{$\begin{array}{l}\text { Fig. 905. } 21 / 2 \mathrm{in} \text {. Spray Pump with } x \text { in. } \\
\text { rion suction pipe with brass strainer and one } \\
\text { lead of I5 ft," } 1 / 2 \text { in., discharge hose, with } \\
\text { "Mistry" or "Seneca" Spray Nozzle. } \\
\text { Fig. 905. } 3 \text { in. Spray Pump fitted in same } \\
\text { manner. }\end{array}$} & $\begin{array}{r}14.00 \\
15.00\end{array}$ \\
\hline $\begin{array}{c}\text { Outfit D. } \\
\text { with two } \\
\text { leads of hose } \\
\text { and nozzles. } \\
\text { Outfit DD. }\end{array}$ & \multicolumn{4}{|c|}{$\begin{array}{l}\text { Fig. 905. 21/2 in. Spray Pump with } \mathrm{r} \text { in. } \\
\text { iron suction pipe with brass strainer and two } \\
\text { leads of } 15 \mathrm{ft} \text {. each, } 1 / 2 \text { in, discharge hose, with } \\
\text { "Mistry" or Seneca "Spray Nozzles. } \\
\text { Fig. 905. } 3 \text { in. Spray Pump fitted in same } \\
\text { manner. }\end{array}$} & 18.50 \\
\hline
\end{tabular}

For Extra Hose, Nozzles, Extensions, etc., see pages 28 to 33 . 


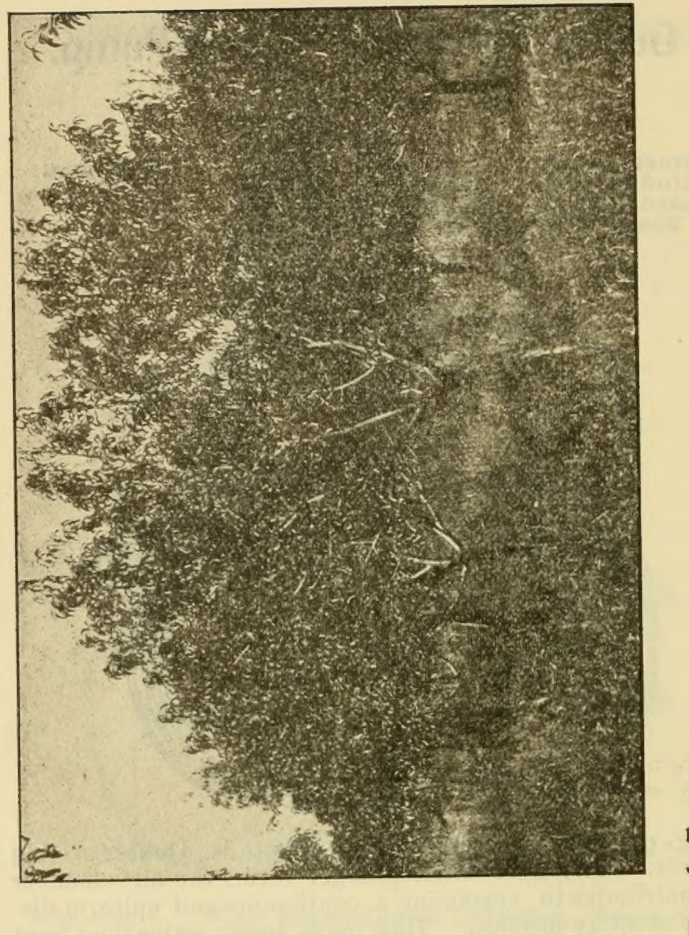

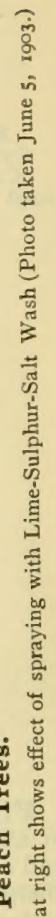

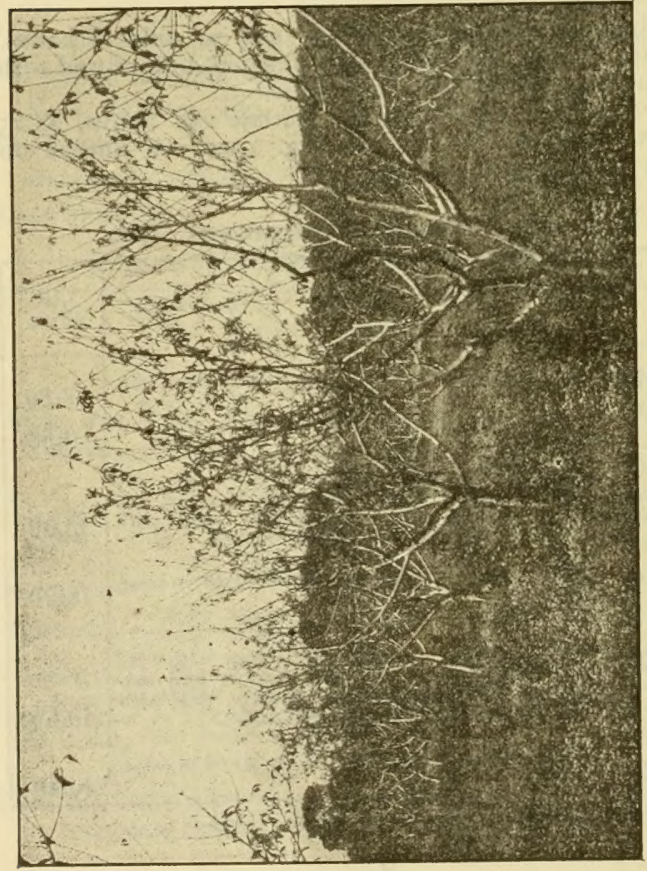

音 


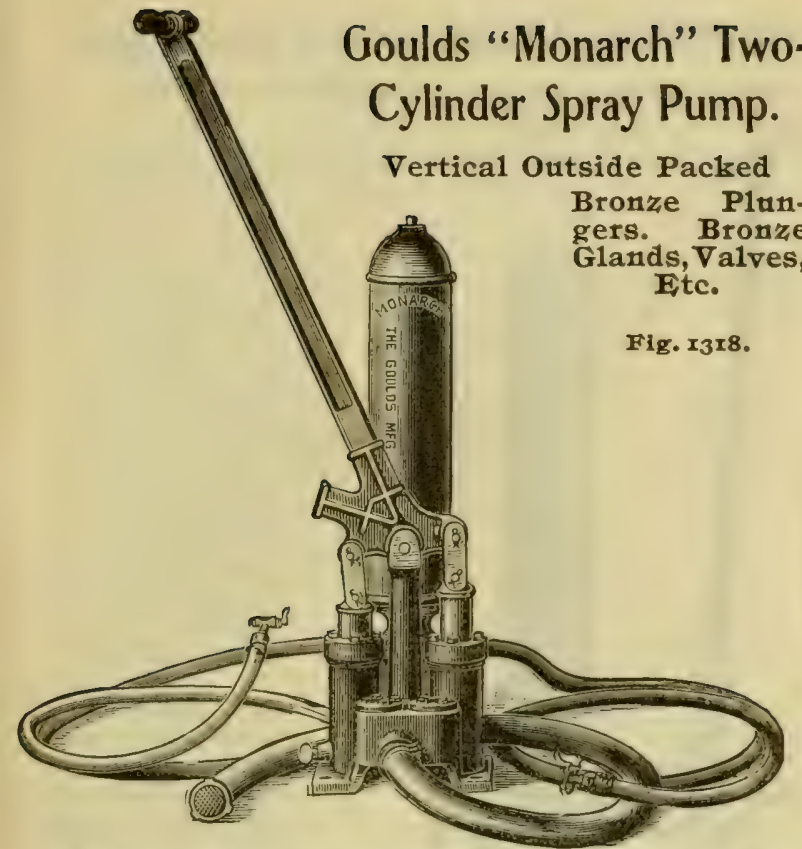

Fig. I318 "Monarch" has two bronze plungers operating in two vertical cylinders, which are packed with a material uneffected by spraying solutions. This construction permits all gritty particles to pass through the Valves and out; and does not grind the cylinder. The ports are large and direct. The valves are bronze, ground to fit their bronze seats, are accessible through hand holes. The lever is so arranged as to be operated in two positions. The "Monarch" combines large capacity and ease of operation, and we do not hesitate to say that this is the easiest operated Pump of its capacity on the market.

Fig. I318. Pump, Equipment, Etc.

\begin{tabular}{|c|c|c|c|c|c|}
\hline & No. & $\begin{array}{l}\text { Dia. } \\
\text { Cyls. }\end{array}$ & Suction. & $\begin{array}{c}\text { Double } \\
\text { Discharge. }\end{array}$ & \begin{tabular}{|l} 
List \\
Price.
\end{tabular} \\
\hline \multirow{2}{*}{$\begin{array}{c}\text { Pump with } \\
\text { Strainer and } \\
\text { Hose Couplings. }\end{array}$} & 。 & 2 in. & $\begin{array}{l}3 / 4 \text { in. } \\
\text { hose. }\end{array}$ & I/2 in. hose. & $\$ 22.50$ \\
\hline & & $2 / 2 \mathrm{in}$. & $\begin{array}{l}x \text { in. } \\
\text { hose. }\end{array}$ & I/2 in. hose. & 29.25 \\
\hline Outfit C. & \multicolumn{4}{|c|}{$\begin{array}{l}\text { Fig. I3r8. } 2 \text { in. fitted with } 5 \text { ft. } 3 / 4 \\
\text { in. suction hose with strainer and } I \\
\text { leird } 1 / 2 \text { in. discharge hose } 15 \mathrm{ft} \text {. long, } \\
\text { with one "Mistry" (or other) Spray } \\
\text { Nozzle. }\end{array}$} & 29.25 \\
\hline Outfit CC. & \multicolumn{4}{|c|}{$\begin{array}{l}\text { Fig. } 13 \times 8.2^{1 / 2} \text { in. fitted up in same } \\
\text { manner except has } 1 \text { in. suction hose. }\end{array}$} & 36.50 \\
\hline Outfit D. & \multirow{2}{*}{\multicolumn{4}{|c|}{$\begin{array}{l}\text { Fig. I318. } 2 \text { in. fitted with } 5 \text { ft. lead } \\
\text { of } 3 / 4 \text { in. suction hose with strainer and } \\
2 \text { liuds } 1 / 2 \text { in. discharge hose each } 15 \mathrm{ft} \text {. } \\
\text { long each with one "MIistry" (or other) } \\
\text { Spray Nozzle. } \\
\text { Fig. I3I8. } 21 / 2 \text { in. fitted in same manner } \\
\text { except has I in. suction hose. }\end{array}$}} & 33.75 \\
\hline Outfit DD. & & & & & 41.00 \\
\hline
\end{tabular}

Hose can be furnished in any length and any desired number of leads. Double Nozzle, Extensions, etc., pages 28 to 33. 


\section{"Sentinel Jr." Double-Acting Spray Pump}

\section{Removable Lining. Outside Guided Piston.}

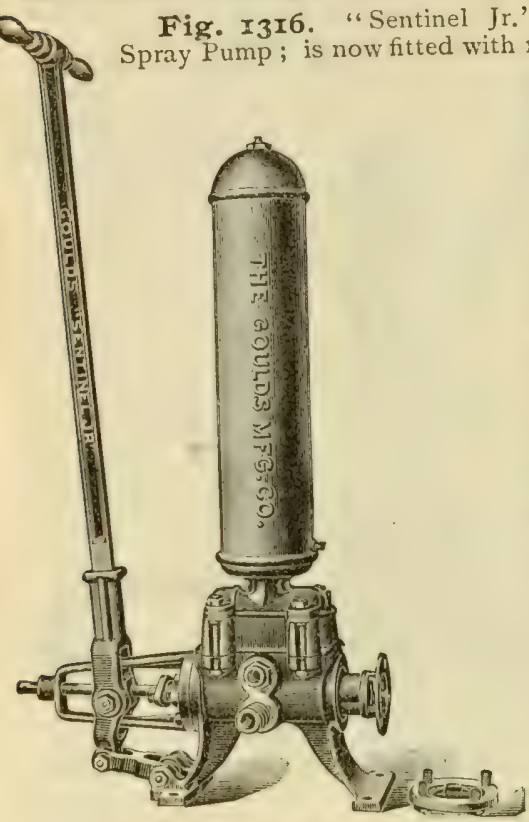

Fig. $13 \times 6$.

Cylinder Cap removed and Lining partly withdrawn.
Double-Acting eminvable lining, which consists of a heavy brass tube with cast bronze flanged head. This can be quickly withdrawn by removing cylinder head, as shown in illustration, and renewed at a minimum cost. The orchardist who is aware of the gritty nature of many spraying solutions and consequent wear on pump cylinder, will appreciate this new feature. $\quad \mathrm{The}$ brass piston rod is outside guided and the piston easily removed for repacking. Stuffing box is tightened or re. packed from outside. The bronze valves and seats

are easily accessible for examination. Extra large air chamber $6 \times 30$ inches. Suction and discharge connections can be made at either side of pump. Pump ordered without hose has one $I$ inch suction and two $1 / 2$ inch Discharge Brass Hose Couplings, also Brass Strainer.

Fig. r3r6. Pump, Equipment, Etc.

\begin{tabular}{|c|c|c|c|c|}
\hline & Dia. Cyl. & Suction. & $\begin{array}{c}\text { Double } \\
\text { Discharge. }\end{array}$ & $\begin{array}{c}\text { List } \\
\text { Price. }\end{array}$ \\
\hline $\begin{array}{c}\text { Pump with } \\
\text { Strainer and } \\
\text { Hose Couplings. }\end{array}$ & $21 / 2$ in. & $x$ in. hose. & $1 / 2$ in. hose. & $\$ 25.00$ \\
\hline Outfit G. & \multicolumn{3}{|c|}{$\begin{array}{l}\text { Fig. I3 } 16 \text { with } 5 \text { feet } x \text { inch rubber } \\
\text { suction hose and strainer and one } 25 \text { foot } \\
\text { lead of } 1 / 2 \text { inch discharge hose with one } \\
\text { "Mistry" (or" Seneca") Spray Nozzle. }\end{array}$} & 32.75 \\
\hline Outfit $\mathrm{H}$. & \multicolumn{3}{|c|}{$\begin{array}{l}\text { Fig. I3I6 with } 5 \text { feet I inch rubber } \\
\text { suction hose and strainer and two } 25 \text { foot } \\
\text { leads of I Inch discharge hose each with } \\
\text { lone "Mistry" (or "Seneca") Spray } \\
\text { Nozzle. }\end{array}$} & 38.25 \\
\hline Outfit I. & \multicolumn{3}{|c|}{$\begin{array}{l}\text { Fig. 13I6 with } 5 \text { feet } \mathrm{x} \text { inch rubber } \\
\text { stuction hose and strainer and four } 25 \\
\text { foot leacls of t/ inch discharge hose each } \\
\text { with one "Mistry" (or "Seneca") } \\
\text { Spray Nozzle. }\end{array}$} & 50.25 \\
\hline
\end{tabular}

Hose can be furnished in any length and any number of leads, Double Nozzles, Extensions, Etc., see pages 28 to 33 . 


\section{Goulds "Sentinel" Double-Acting Spray Pump.}

\section{Brass-1ined Cylinder, Bronze Valves, Piston, Piston Rod, Etc.}

Goulds "Sentinel" Double-Acting Spray Pumps are used throughout the large apple orchards and orange groves because of their large capacity and great power. Capacity is sufficient to supply eight or more nozzles. Sometimes six nozzles are used on one discharge. Sometimes four leads of hose are used. Piston is easily and quickly repacked and valves easily accessible. Piston, piston rod, valves and seats and cylinder lining are brass.

Pumps ord ered without hose $h$ ave I $1 / 4$ in. suction and two $1 / 2$ in. discharge brass hose couplings, also brass strainer, Brass "Y's" for fitting two leads of discharge hose on a side furnished when ordered.

Air-chamber $6 \mathrm{x}_{30}$ in., as shown in outline, furnished in place of regular airchamber, 5x21 1/2 in., at additional $\mathrm{l}$ is $\mathrm{t}$ $\$ 2.50$.

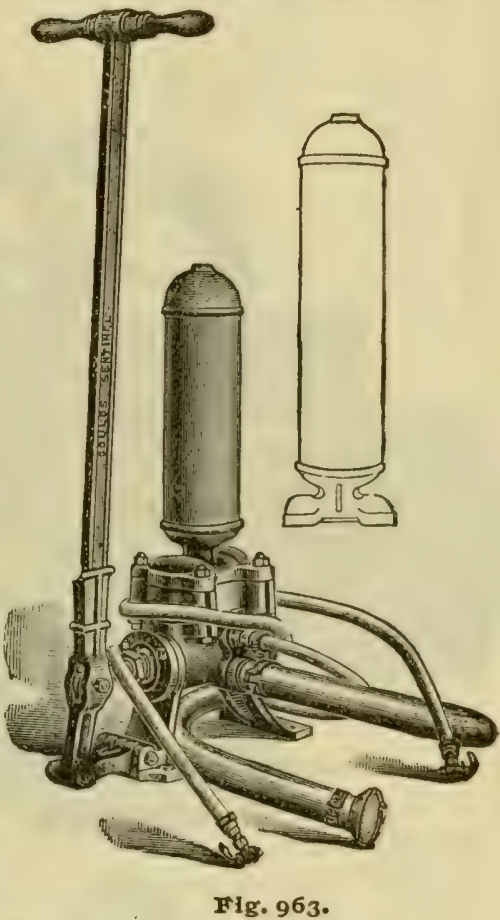

Fig. 963. Pump, Equipment, Etc.

\begin{tabular}{|c|c|c|c|c|}
\hline & $\begin{array}{l}\text { Dia. } \\
\text { Cyl. }\end{array}$ & Suction. & $\begin{array}{l}\text { Double } \\
\text { Discharge. }\end{array}$ & $\begin{array}{c}\text { List } \\
\text { Price. }\end{array}$ \\
\hline $\begin{array}{l}\text { Pump with } \\
\text { Strainer and } \\
\text { Hose } \\
\text { Couplings. }\end{array}$ & 3 in. & $13 / 4$ in. hose. & 1/2 in. hose. & $\$ 22.50$ \\
\hline Outfit $\mathrm{H}$. & \multicolumn{3}{|c|}{$\begin{array}{l}\text { Flg. } 963 \text { with } 5 \text { ft. } 11 / 4 \text { in. rubber } \\
\text { suction hose and strainer and two lead's } 25 \\
\text { ft. each, } 1 / 2 \text { in. discharge hose, with" Nlistry" } \\
\text { (or other) Spray Nozzles, couplings and } \\
\text { hose bands complete. }\end{array}$} & 36.00 \\
\hline Outfit 1. & \multicolumn{3}{|c|}{$\begin{array}{l}\text { Fig. } 963 \text { with } 5 \text { ft. IT/4 in. rubber } \\
\text { suction hose and strainer, brass "Y's" and } \\
\text { four leads } 25 \mathrm{ft} \text {, each, I in. discharge hose } \\
\text { with "Mistry " (or other) Spray Nozzles, } \\
\text { couplings and hose bands complete. }\end{array}$} & 48.00 \\
\hline
\end{tabular}

Hose can be furnished in any length and any desired number of leads. Double Nozzle, Extensions, etc., pages 28 to 33 . 


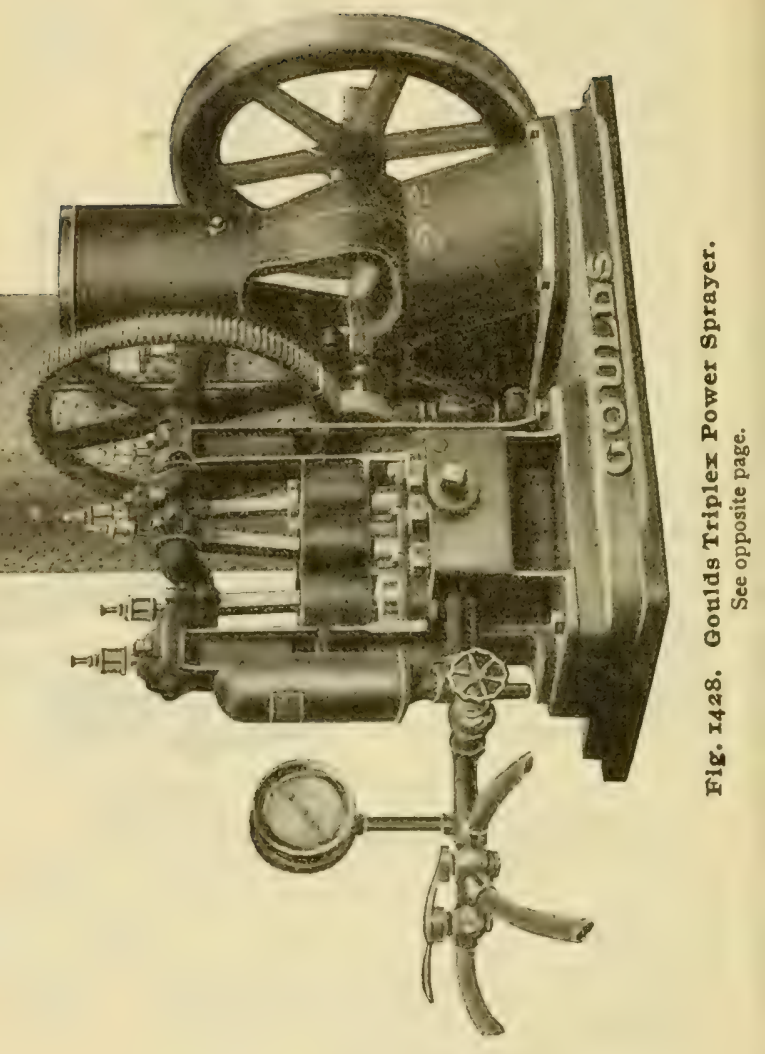




\section{Goulds Triplex Power Spraying Outfit.}

While we have been making for years Spraying Outfits operated by Gasoline Engines and used by municipalities in the protection of shade trees, it was not until within the last few years that we made an outfit particularly adapted for orchard work. This year we have made some decided improvements.

The Pump and Engine are direct conn ected by coupling and reduction gearing and are mounted on a cast iron bed. plate 36 by 21 inches, which extends under both Pump and Engine. The Engine can be separated from the Pump in a short time and used independently when desired.

The Pump is one of our modern Triplex Plunger Pumps originated and perfected by us and now used for every service.

Fig. I428 Power Syraying Outfit consists of a $1 \frac{1}{2}$ Horse power portable Gasoline Engine complete with electric ignitor including battery, spark coil, cooling tank, etc., a Bronze Fitted Triplex Pump with water relief valve, 200 pound pressure gauge, brass discharge shutoff with hose couplings for four leads of hose, 5 feet of suction hose and strainer. When so ordered we can supply half round tank to fit in bolsters of wagon.

It is made with three vertical outside packed plungers operated by a crank shaft in such a manner as to insure smooth flow of liquid and an even pressure with the least possible power. All valves and seats are made of phosphor bronze and the valves are made with long winged guides so arranged as to give a revolving motion when water passes through them. This prevents the valves from always seating in the same position. The valves are easily accessible for examina. tion by removing the valve covers. The glands are the best phosphor bronze and can be removed from the outside so that the Pump can be easily repacked. All the working parts coming in contact with the liquid are of phosphor bronze.

We have this year selected the best known Gasoline Engine on the market; not attempting to use the cheap unknown engines. We will gladly furnish full information in regard to Engine upon application. 

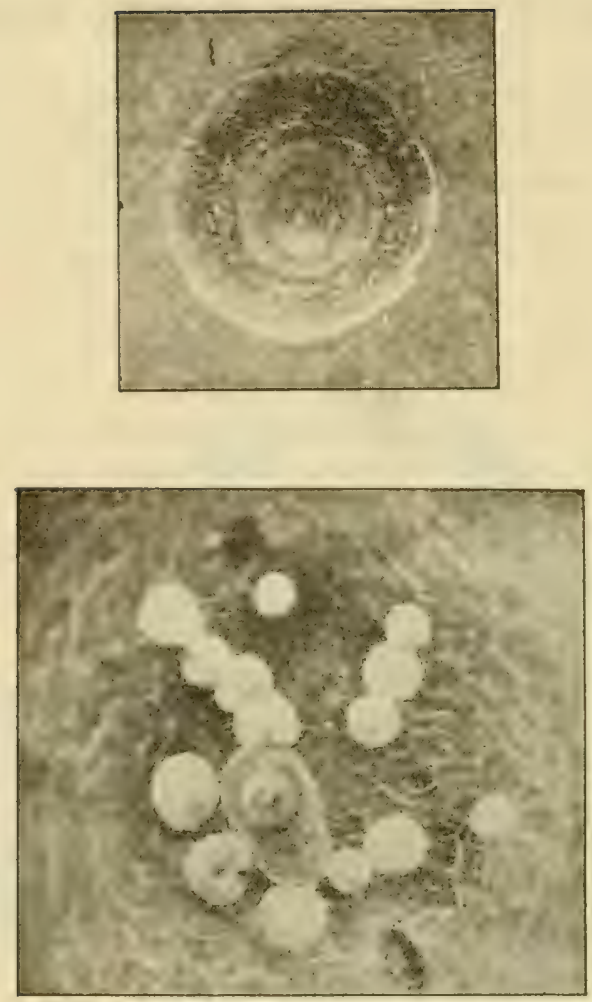

में

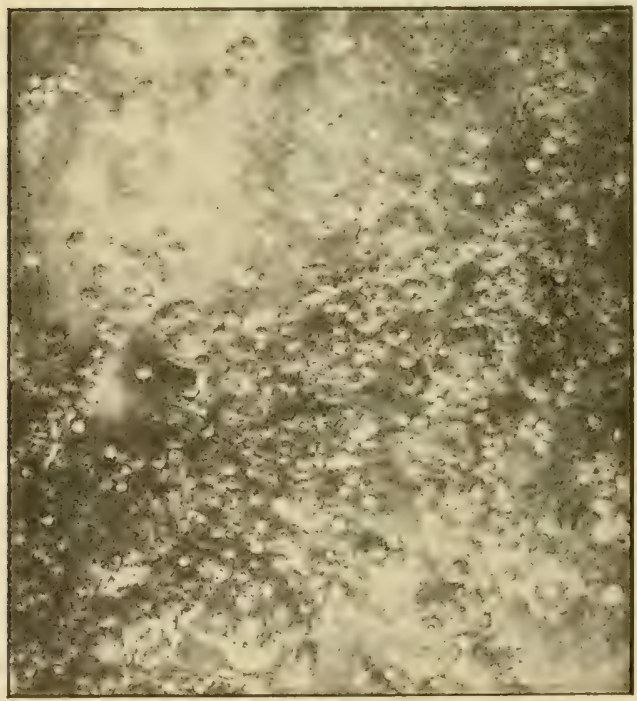



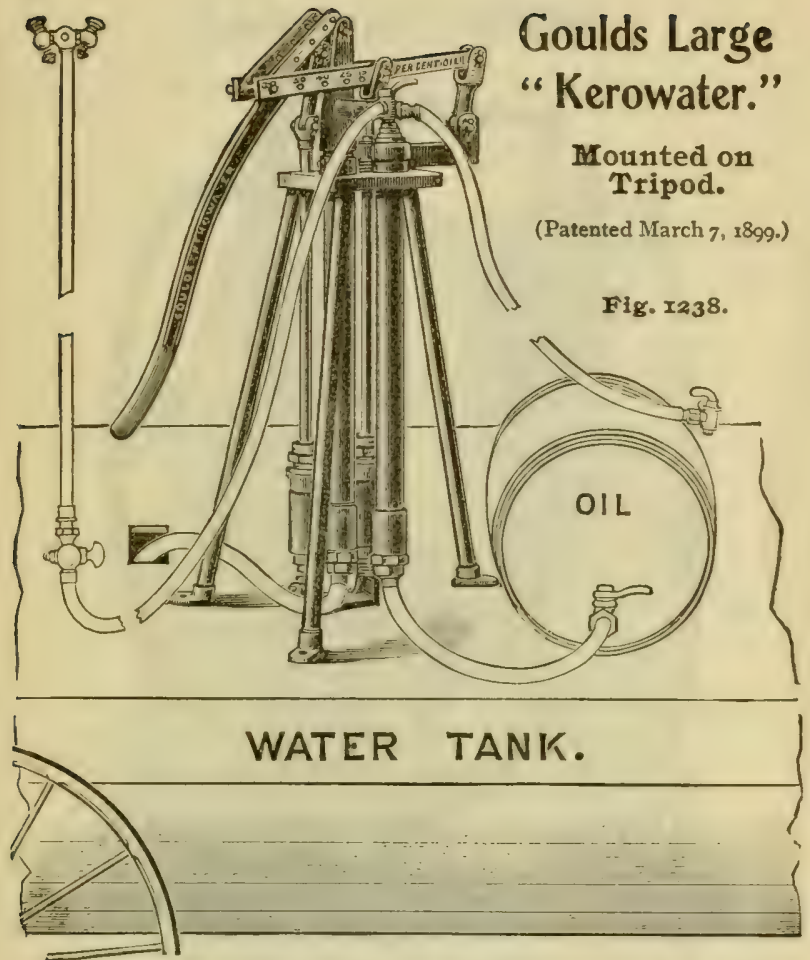

Fig. 1238, is designed upon same principles as Fig. I I 87 described on page is. It has, however, larger capacity, and handles larger percentages of oil-either $15,25,40,50$ or 60 per cent.

Oil and water are drawn through suction hose. Always use as short suction as possible, and where convenient have suction flooded.

Pump is equally well adapted for handling Bordeaux or other spraying liquid. All working parts-I'lungers, glands, valves, etc., are of Brass.

Can furnish outfits with any length of hose.

In place of regular spray hose listed in outfits below we can furnish at additional cost a special discharge hose made to better withstand the action of kerosene.

Can fit Fig. 1238 , wellen so ordered, with combination discharge as described under Fig. $11871 / 2$, page 19.

Fig. 1238. Pump, Equipment, Etc.

\begin{tabular}{|c|c|c|c|c|}
\hline & Dia. Plungers. & Suction. & Discharge. & List. \\
\hline $\begin{array}{l}\text { Pump with one } \\
\text { Strainer and one } \\
\text { Barrel Attachment } \\
\text { (no hose or noz- } \\
\text { zles). }\end{array}$ & $2 \mathrm{in}$. & $3 / 4$ in. & $1 / 2$ in. & $\$ 22.50$ \\
\hline \multicolumn{4}{|c|}{$\begin{array}{l}\text { Outfit C. Fitted with } 4^{T / 2} \text { feet of water suction hose with } \\
\text { Brass Strainer, } 3 \text { feet of special kerosene suction hose with } \\
\text { barrel attachment; also double discharge shut-off and one } 15 \\
\text { feet lead } 1 / 2 \text { inch spray hose and "Mistry" Nozzle. }\end{array}$} & 30.75 \\
\hline \multicolumn{4}{|c|}{$\begin{array}{l}\text { Outfit D. Same as Outfit A, with addition of a second I5 } \\
\text { feet lead of spray hose and nozzle. }\end{array}$} & 34.00 \\
\hline
\end{tabular}




\section{Goulds "Kerowater."}

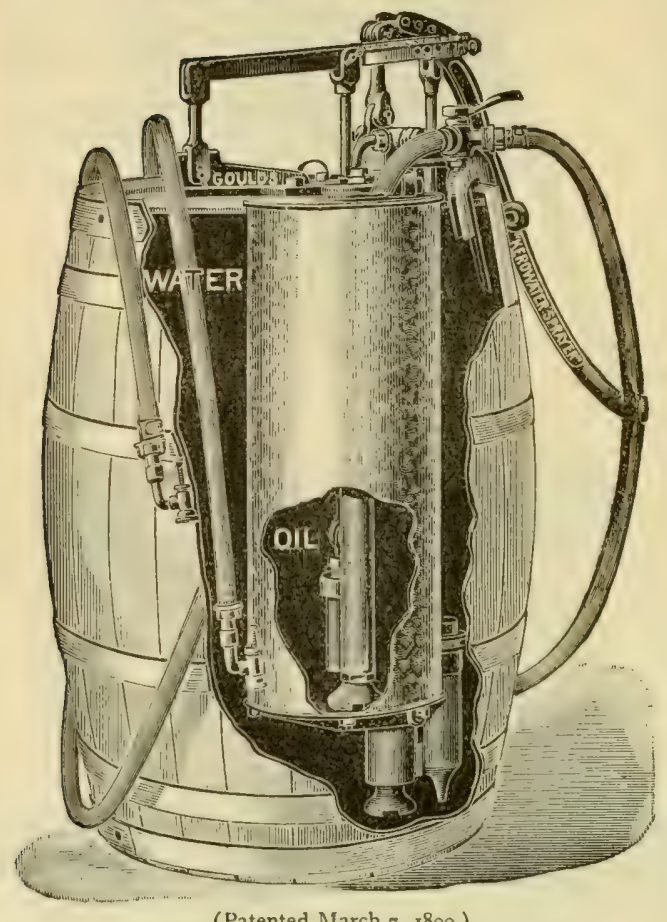

(Patented March 7, 1899.)

Fig. Ir87, "Kerowater " mechanically mixes and sprays kerosene or crude petroleum and water. Either 5, 10, 15, 20 or 25 per cent. oil can be used.

A galvanized iron tank, containing oil goes inside of a barrel, containing water. Inside of oil tank is a Pump, and out. side is another Pump. Both Pumps are operated by one common lever. They both discharge at a common point, where the water and oil are blended.

Percentage of oil is varied by changing pin in the lever. Pump is a positive measuring device and delivers exact percentages of oil. Outfit is readily removed from barrel. Oil tank anci Pump can be removed and the water Pump used for general spraying. Water Pump is similar to Fig. IISS, page 7 , and at $\$ 1.25$ extra list we can supply Agitator. All working parts are of Bronze.

We can furnish outfits with any desired length of hose. In place of regular spray hose listed in outfits below, we can furnish at additional cost a special hose made to better withstand the action of kerosene.

Fis.Ir87. Pump, Fquipment, Etc.

\begin{tabular}{|c|c|c|}
\hline $\begin{array}{l}\text { Pump mounted in Barrel and fitted with } \\
\text { Brass Double Shut-off with } 2 \text { half-hose } \\
\text { couplings (No hose or Nozzles). }\end{array}$ & Discharge. & $\begin{array}{l}\text { List } \\
\text { Price. } \\
21.00\end{array}$ \\
\hline \multicolumn{2}{|c|}{$\begin{array}{l}\text { Outfit C. Pump mounted as above; fitted with one } 15 \mathrm{ft} \text {. } \\
\text { lead } 1 / 2 \text { in. spray hose with "Mistry" Nozzle. }\end{array}$} & 24.50 \\
\hline $\begin{array}{l}\text { Outfit D. Pump mounted as above with tzeo } \\
1 / 2 \text { in. spray hose with "Mistry" Nozzles. }\end{array}$ & $15 \mathrm{ft}$. leads & 28.00 \\
\hline
\end{tabular}




\section{Goulds "Kerowater."}

\section{With Separate Oil and Water Hose.}

(Patented March 7, 1899.)

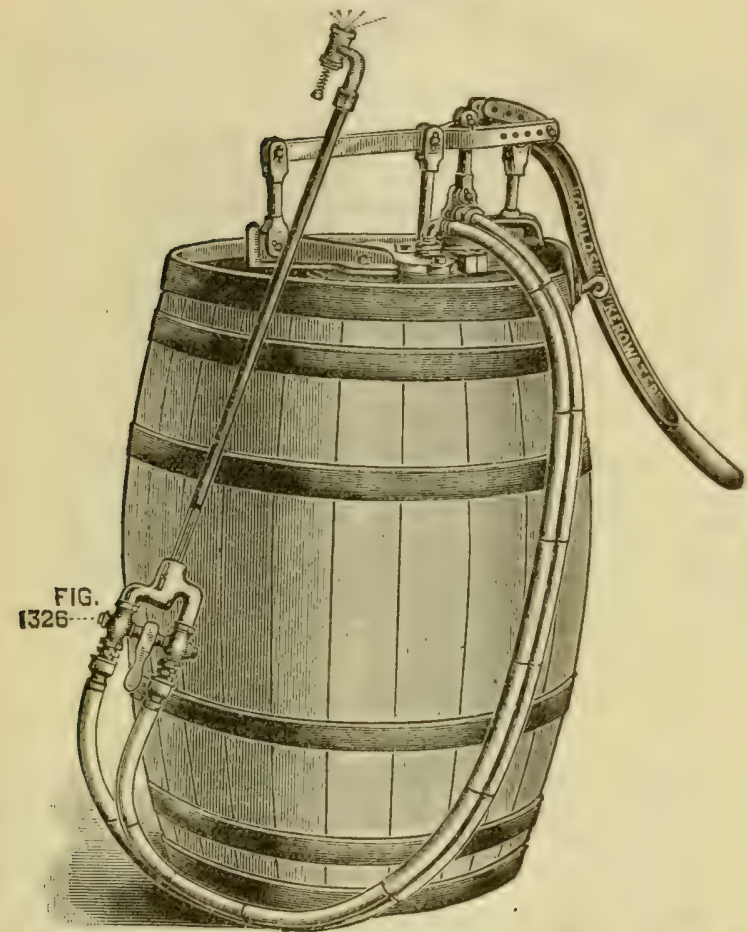

Fig. II $87 \mathrm{I} / 2$ differs only from Fig. II $S_{7}$ on opposite page in that the oil is conveyed to the nozzle through one hose and the water through another. The two hose are banded together as shown in cut. By this arrangement, mixture is made at the nozzle instead of at pump. Hose used is $3 / 8$ in. and oil hose is specially made to better withstand action of kerosene.

When pipe extension is wanted our special Fig. I326 is required and costs extra $\$ 0.00$ list. This extension is $8 \mathrm{ft}$. long, has brass double shut-off and is made with brass pipe inside of $1 / 4 \mathrm{in}$. iron pipe, oil being conveyed through former and water through latter and thus kept separate till nozzle is reached.

We can furnish outfits with any desired length of hose.

Fig. $11871 / 2$. Pump, Equipment, Etc.

\begin{tabular}{|c|c|c|}
\hline Pump mounted in barrel and fitted with & Discharge. & $\begin{array}{l}\text { List } \\
\text { Price. }\end{array}$ \\
\hline extension.) & $3 / 8$ in. & $\$ 21.00$ \\
\hline \multicolumn{2}{|c|}{$\begin{array}{l}\text { Outfit C. Pump mounted in barrel and fitted with } \\
15 \mathrm{ft} \text {. lead combination discharge comprising } 3 / 8 \text { in. water } \\
\text { and } 3 / 3 \text { in. special kerosene hose banded together and } \\
\text { fitted with "Mistry" Nozzle. (Pipe extension extra.) }\end{array}$} & 29.00 \\
\hline
\end{tabular}




\section{Goulds Knapsack “ Kerowater."}

\section{For Emulsifying and Spraying Kerosene and Water.}

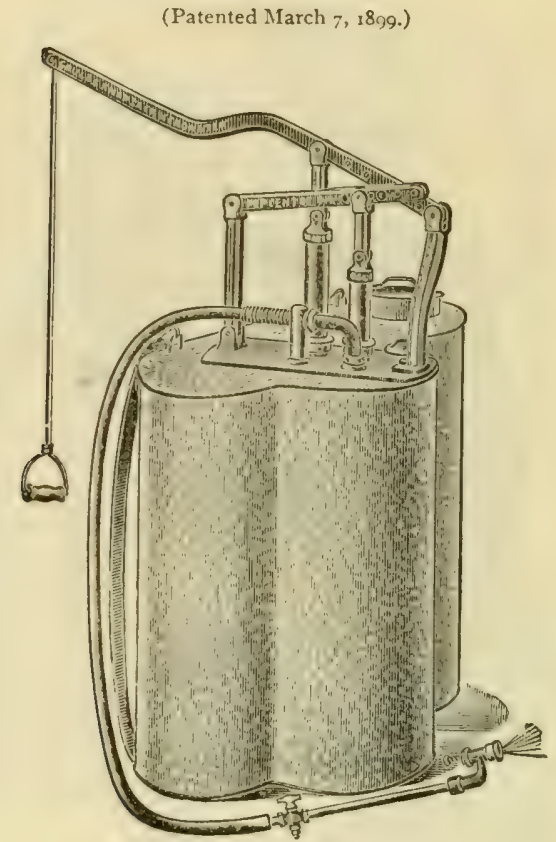

Fig. I263.

Many conditions are encountered under which our barrel "Kerowater" cannot be advantageously operated, as in greenhouses, work on side hills, etc. For these purposes we have designed our Irig. 1263 Knapsack "Kerowater."

It has a galvanized iron tank provided with straps for carrying on back or may be used with reservoir resting on ground. It embodies the same principle as described under Fig. Ir $S_{7}$ (page IS) and consists of two independent Pumps, operated by a common lever, placed in the tank with divisions for oil and water. Capacity of tank about 5 gallons. Quan. tity of oil used is controlled by adjustment of a single pin, and may be varied to $5,10,15,20$ or 25 per cent. Pump may be operated by either hand, by changing lever to right or left.

\section{Fig. I263. Equipment, Etc.}

Fig. 1263. Knapsack "Kerowater" complete as shown in cut with $4 \mathrm{ft}$. of $3 / 3$ in, discharge hose, "Mistry" Nozzle and Pipe Extension, 15 in. long with stop cock. List $\$ 12.00$

For "Spraying Calendar," Formulas, etc, see Pages 34 to 40 . 


\section{"Handy" Knapsack Pump.}

\section{For Vineyard, Greenhouse or Field Service.}

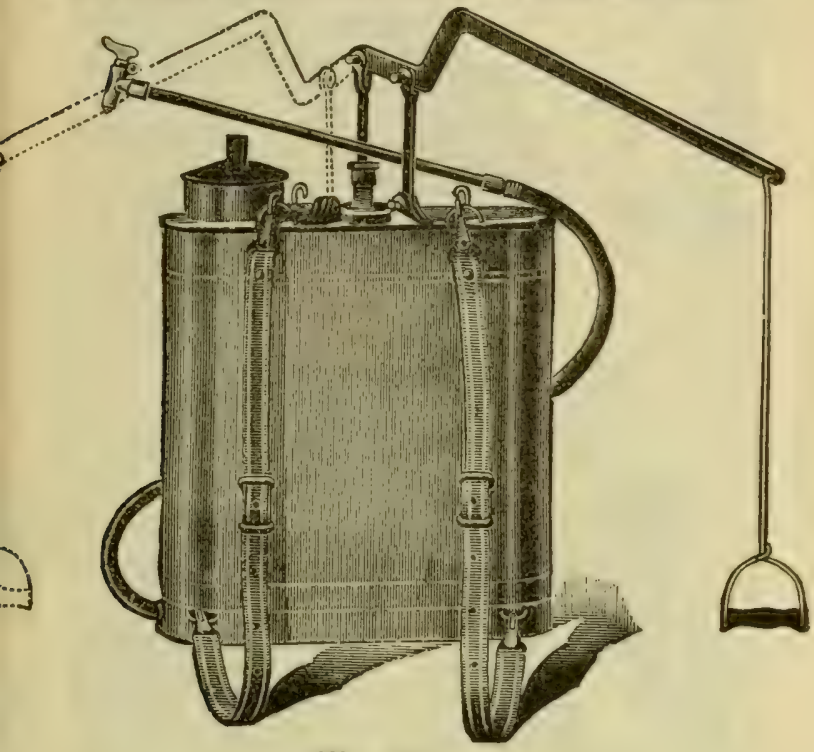

Fig. 989.

Fig. 989 has copper tank and brass pump, with ball valves and metal plunger, all of which are easily accessible.

The discharge is at the bottom, and the Pump can be entirely drained of the liquid. Any leakage of fluid out of the stuffing-box will drip back into the tank. The change from the right to the left hand is simple, and made by disconnecting the bearer link and bringing it over to the jaw provided for it on the other side.

An eye on the top and back of knapsack enables one to suspend it steadily when he wishes to take it off from his back. It should be carried on back with the straps crossed in front.

The reservoir is made of heavy copper, and will hold about five gallons of liquid.

Special Agitator................... \$0.50 extra net.

Fig. 989. Equipment, Etc.

Fig. 989. "Handy" Knapsack Sprayer, complete as shown in cut, with $31 / 2$ feet of $3 / 8$ inch discharge hose, with brass Extension pipe and "Seneca" (or other) Nozzle.

For "Spraying Calendar" Formulas, etc, see pages 34 to 40 . 


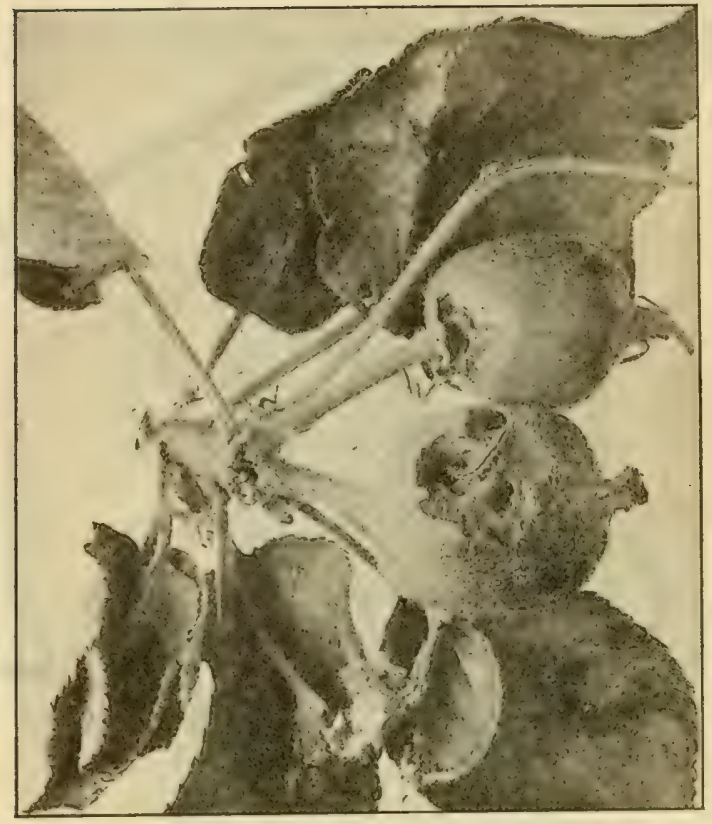

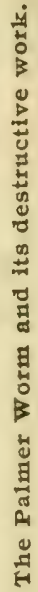




\section{Goulds Brass Bucket Pumps.}

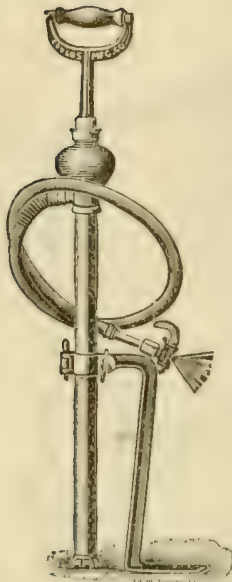

Fig: Ir29, "Bordeaux" Brass Gar. den and Spray Pump, is especially designed for spraying in gardens and greenhouses. The Pump is doubleacting in effect, has Gutta Percha ball valves, proof against the action of acids and oils. Foot piece is malleable iron. The pump end of discharge hose is wire wound, adding largely to its durability. Our "Seneca." nozzle is furnished with Pump (see description, page 29). Pump has no suction hose, but is set in pail or bucket with foot-rest outside.

F1g. Ix29.

Fig. Ir29. Equipment, Etc.

With 3 feet $3 / 8$ inch discharge hose and "Seneca" Spray Nozzle. List price, $\$ 6.00$

Fig. 56r $1 / 2$ represents our "Premier" Brass Bucket Pump arranged with suction and discharge hos e and Spray Nozzle. With this nozzle a solid stream may be thrown or a fine spray. Pump has brass cylinder, plunger and rod. Pump is particularly adapted for washing windows and wagons, spraying flowers in conservatories, gardens, etc. Its weight is only

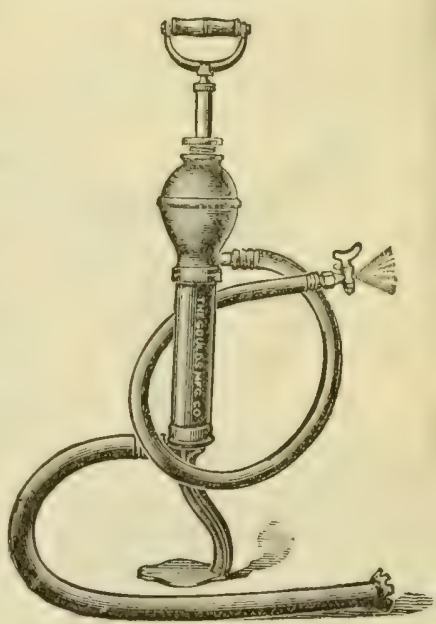

Fig. $56 I^{1 / 2}$. eight pounds.

\section{Fig. 56r1/2. Equipment, Etc.}

\section{With $2^{1 / 2}$ feet $3 / 4$ inch suction and 3 feet $3 / 8$ inch discharge hose, "Seneca" Spray Nozzle and Strainer. $\quad$ List price, $\$ \mathbf{\$ 7 . 5 0}$}

For "S;raying Calendar," Formulas, etc, see pages 34 to 40. 


\section{Goulds Field Crop Sprayer.}

\section{Jsed in Connection with any Hand or Power}

Spray Pump.

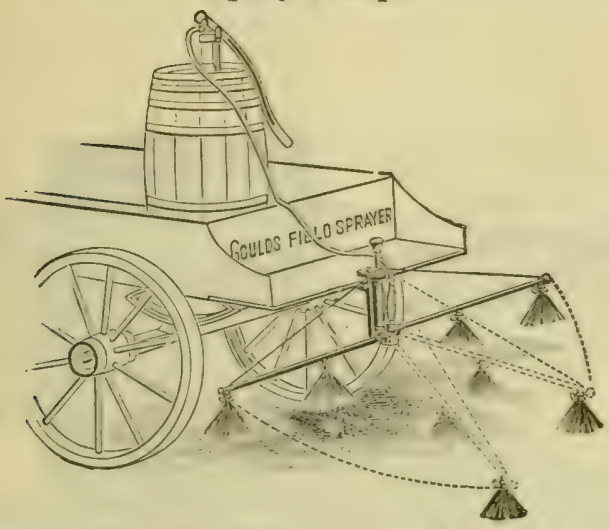

Fig. I322 consists of two sections of iron pipe, (having or 6 Nozzles) hinged at one end and fastened to wagon ittachment. It is made to spray four or six rows, any disance apart up to 44 inches, or cover a space $141 / 2$ or 22 feet $\mathrm{n}$ width. Connection allows Sprayer to be easily raised or owered; spray to be thrown, forward, backward, up or down. $t$ may be folded to pass anywhere with the wagon. It is he simplest, cheapest and most convenient sprayer of its rind.

Pump and hose not included in price.

Fig. 1322. Equipment, Etc.

Complete with four "Mistry" or "Seneca" Nozzles and coupling for connecting to discharge hose of any t.arrel or power sprayer. $\$ 10.00$ Same with six "Mistry" or "Seneca" Nozzles.

$\$ 12.50$

\section{Independent Revolving Agitator.}

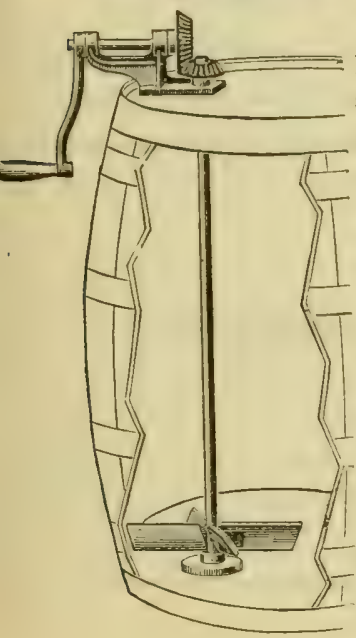

Fig. rro2, Independent Revolving Agitator, offers advantages ov e $r$ anything yet devised. Power is transmitted through a small pair of bevel gears to a paddle wheel, comprising four arms set at such an angle that as the wheel revolves the liquid is carried both around and upwards in the barrel, thus insuring thorough agitation of the entire contents of the barrel.

Fig. 1102. Goulds Revolving Agitator only. List price, $\$ 5.00$ 


\section{Goulds Barrel Cart.}

\section{Fnr use with any of our Barrel Spray Pumps.}

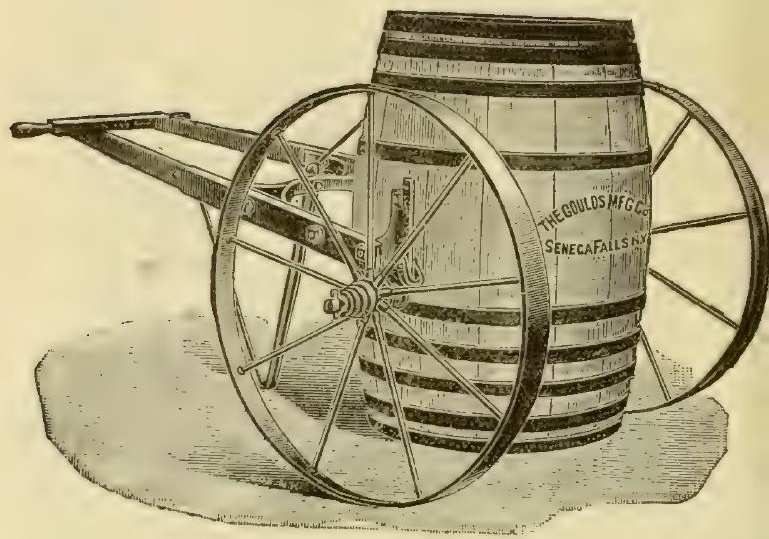

Fig. Ir33. Improved Barrel Cart is found useful both for spraying and as a watering cart. Any of our Barrel Spray Pumps can be mounted in it and we will supply outfit complete at price of the particular Spray Pump or "Outfit" selected plus price of Barrel Cart with Barrel.

Running gear when purchased separately may easily be attached to any good Barrel. Wheels have $21 / 2$ inch tires. Barrel can be picked up and deposited by simply elevating and lowering the handles.

Fig. Ir33. Equipment, Etc.

Cart complete without Barrel. List Price . . . . . . . \$10.00

Cart complete with Barrel (no Pump). List price . . . . . . . \$12.50

Cart complete with Barrel and Pump at additional price of particular Pump or "Outfit" selected. 


\section{Goulds Spraying Tanks.}

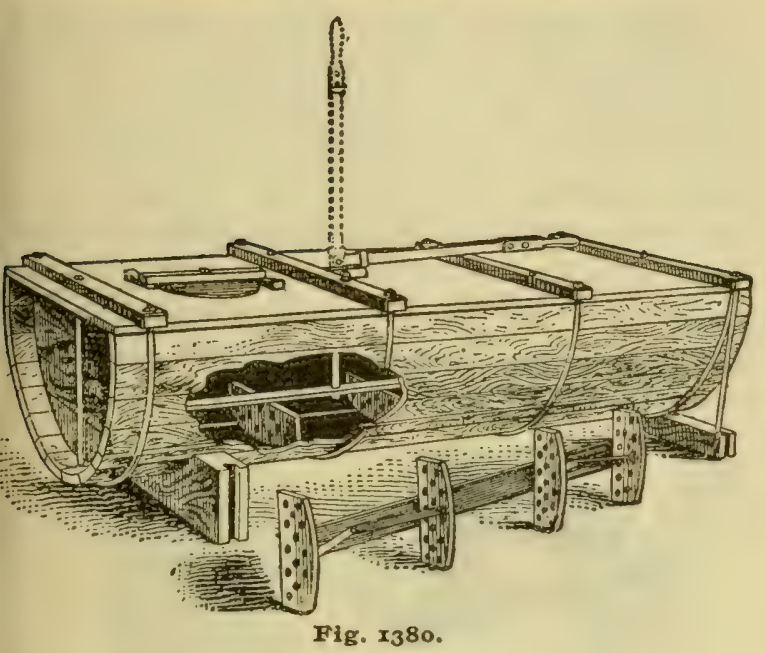

Fig. I380 shows a Wooden Spraying Tank built from the ideas of some of the largest fruit growers in Westem New York.

The staves are made of $1 / 2$ inch pine, strongly gripped with steel and hard wood. The joints are machine made and are perfect. The tank weighs about 200 pounds, is eight feet long, three feet wide, and holds 200 gallons of liquid. It has one tight and one loose bolster and will set on the bolsters of any ordinary farm wagon. The top of Tank is very strong and allows Sfray Pump to be firmly fastened thereon, and also will accommodate the operator. Tanks furnished with or without an agitator. The agitator (see engraving) keeps the liquid thoroughly stirred all the time, so the last gallon of spraying mixture is just as strong as the first used. Paddles of agitator are bound with steel and run on a steel track in bottom of Tank. The handle is made so that it can be instantly tipped back in passing under low limbs of trees. Agitator may be taken out through handhole and Tank used for hauling water when wanted.

Fig. I380. Equipment, Etc。

Tank with Bolsters and Agitator. List Price . . . . \$20.00

Above without Agitator. List Price ....... \$ \$18.00

Tanks built to order any size desired. 


\section{Goulds "Mistry" Nozzles.}

Goulds "Mistry" Nozzle is our new production made after many experiments and exhaustive trials. It resembles the "Termorel" in appearance, but surpasses all other Spray Nozzles on the market in results obtained. It produces a perfect mist or for at a very low pressure, -25 pounds being ample to produce as good a spray as is required in good spraying. It can be cleaned by simply pressing against limb of tree. It has thumb screw attachment which allows removal of any foreign substance which may clog the pipe. We offer in two sizes as below.

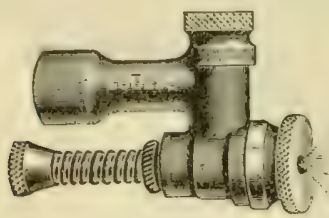

Fig. $x 43 x$.

Fig. I43I, "Mistry" Nozzle throws a spray much finer and greater in area than the "Vermorel" type.

For $1 / 4$ inch pipe. . . . . . . $\$ 1.00$

For hose (including either Fig. 65 or 67 as ordered) . . . . 1.25

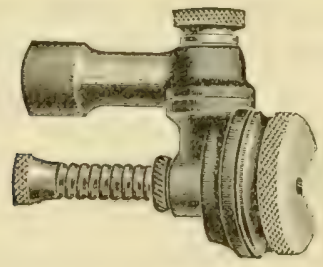

Fig. 1432 .

Fig. I432 is our large "Mistry" Nozzle, which produces a greater area of spray than two Fig. I43I. It has an adjustment which allows the spray to be thrown at any desired angle. In this Nozzle you have the effect of two good Nozzles with only one to attend to, a very good feature.

For $1 / 4$ inch pipe . . . . . . . . . . $\$ 2.00$

For hose (including either Fig. 65 or 67 as ordered) . . . 2.25 


\section{Goulds Spray Nozzles.}

The illustration show s two Fig. 1432 "Mistry" "Nozzles on Fig. 1074 $1 / 2$ Brass "Y." These Nozzles can be adjusted to throw spray in any desired direction; at the same time increasing or decreasing $t \mathrm{~h} \mathrm{e}$

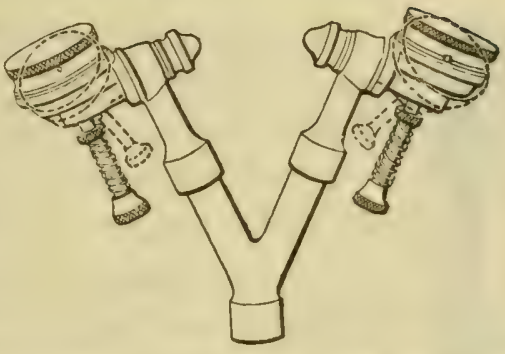
range of spray. This combination is better in effect than four old style "Vermorel " Nozzles.

Fig. 1074 $\frac{1}{2}$ Brass "Y" designed so that two nozzles can be used with one lead of hose, is tapped to fit $1 / 4$ inch pipe at butt, which also adapts it to fit our Figs. 65 and 67 Couplings for hose.

Fig. I074\% $1 / 2$. Brass "Y." ...\$0.50

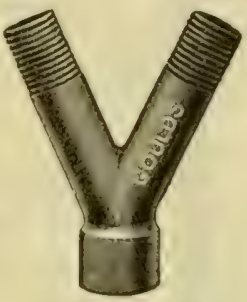

Fig. $1074^{1 / 2}$.

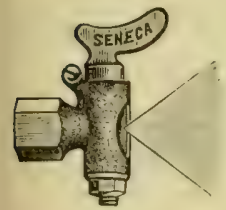

Flg.81.

Fig. $8 \mathrm{I}$ is our "Seneca" spray nozzle which gives a fan shaped spray covering a large area. The nozzle may be cleaned by tuming plug across opening.

Fig. $8 x$ for $x / 4$ inch pipe
Fig. $8 x$ for hose (including either $\$ 1.00$ Fig. 65 or 67 as ordered) 1.25

"Calla" Spray Nozzle.

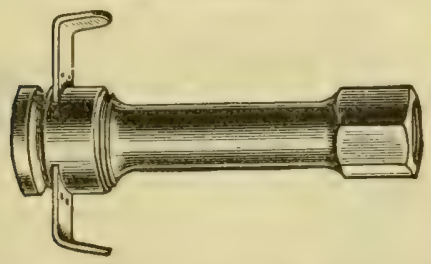

In Fig. $68 \% / 2$, "Calla" Nozzle, the stream is divided before being discharged and so discharged that the streams cut each other, producing a flat fan shaped spray. It can be changed from solid stream to fine or coarse spray by adjustment of slide in cap of nozzle. Regularly cut I/t inch pipe can be turned for wiring into hose when so ordered.

Fig. $68 \frac{1}{2}$. Price cut for $1 / 4$ in. pipe unless otherwise ordered . . . \$ \$0.50 


\section{Goulds Spray Attachments.}

Fig. 1437 represents our New Bamboo Exten. sion made of light $1 / 4$ inch brass pipe inside of selected bamboo rod. Our aim has been to make an extension that would be light to handle and still have strength. It is arranged with brass stop cock cut $1 / 4$ inch female pipe thread thus adapting it for attaching to hose by either Fig. 65 or 67 . Other end cut ${ }_{1 / 4}$ inch male pipe thread to fit nozzles.

Fig. 1437 , of foot with cock. . \$ \$4.50

Fig. I074, Brass " $\mathrm{Y}$ " designed so that two nozzles can be used with one lead of hose, is tapped to fit $1 / 4$ ineh pipe at butt, which also adapts it to fit our Figs. 65 and 67 Coup. Fig. ro74. lings for hose. Any of our various nozzles can be screwed on the branches.

Fig. 1074 , Drass "Y"

Fig. 1437 .

Fig. 49, Brass " $\mathrm{Y}$ " is

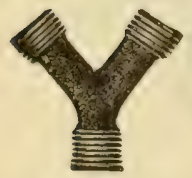
cut $3 / 4$ or $I$ inch male pipe thread on inlet as ordered, and $y / 2$ or $3 / 4$ inch male hose thread on 1 a $\mathrm{t}$ e $\mathrm{r}$ a $l$ discharges.

Fig. 49.

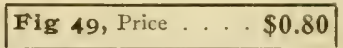

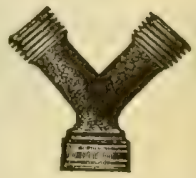

Fig. $49^{1 / 2}$.

Fig. 49 $1 / 2$, Brass " $Y$," is the same in all respects as Fig. 49 described above, except it has female hose thread on inlet. Lateral discharge same as noted.

Fig。 $49^{1 / 2}$, Price $\ldots \ldots \ldots \ldots \ldots \ldots \ldots . \ldots \ldots \ldots$ 


\section{Goulds Spray Fittings.}

Fig. 65 is used to make connection between $1 / 2$ or $3 / 4$ inch hose coupling and Spray Nozzle or Pipe Extension.

One end cut $1 / 4$ inch male pipe thread other end $1 / 2$ or $3 / 4$ inch female hose thread. $\$ 0.25$.

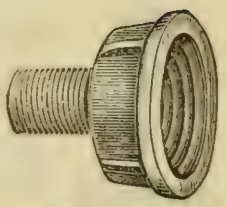

Fig. 65 .

Fig. 67 has one end made to wire into $1 / 2$ or $3 / 8$ inch hose, the other end is cut $1 / 4$ inch pipe thread to attach to Spray Nozzle or Pipe Extension. \$0.25.

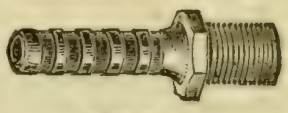

Fig. 67 .

Fig. 89. Brass hose nipple has one end yutm mom cut male pipe thread and other end male hose thread.

Fig. 89.

$1 / 2$ or $3 / 4$ inch hose $3 / 4$ inch iron pipe .......... $\ldots 0.25$

$1 / 2$ or $3 / 4$ inch hose $x$ inch iron pipe .............. 0.25

$1 / 2$ or $3 / 4$ inch hose $x^{1} / 4$ inch iron pipe. . . . . . . . . . . . . 0.50

$\mathrm{r}$ inch hose $\mathrm{x}$ inch iron pipe . . . . . . . . 0.50

I inch hose $x 1 / 4$ inch iron pipe. . . . . . . . . . 0.50

$\mathbf{1}^{1 / 4}$ inch hose $13 / 4$ inch iron pipe

Fig. 70. Brass Suction Pipe Strainer, is fitted for hose as follows :

Price, $3 / 4$ inch . . . . . . $\$ \$ 0.50$

Price, $x$ inch ........ 0.50

Price, $x^{2} / 4$ inch . . . . 1.00

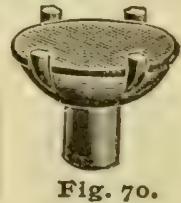

Fig. 7x. Brass Suction Pipe Strainer, is fitted for wrought iron pipe as follows:

Price, $x$ inch ......... $\$ 0.50$

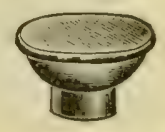

Fig. 7 I.

\section{Pressure Gauge.}

Fig. 301/2. For convenient use in maintaining a desired pressure while spraying. Diameter $3 \frac{1}{2}$ inches. Fitted with stop cock.

Price cut for $1 / 4$ inch pipe . . $\$ 3.50$

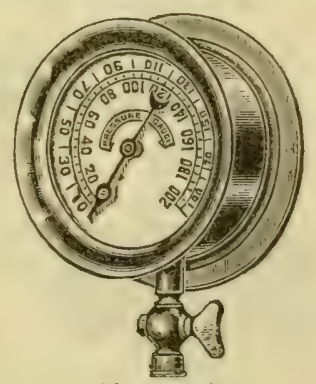

FIg. $30 \mathrm{~T} / 2$. 


\section{Goulds Spray Fittings.}

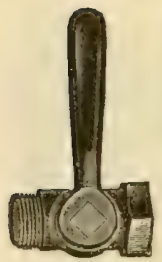

\section{Brass Shut-off Discharge Connection.}

Fig. I092 can be used in connection with any of our larger Spray Pumps to control the discharge at the Pump. One end is threaded to fit the Pump, the other for $1 / 2$ or $3 / 4$ inch hose coupling.

FIg.xo92.

Fig. 1092. Price

$\$ 1.50$

Brass "Y" Discharge Connection with Shut-off.

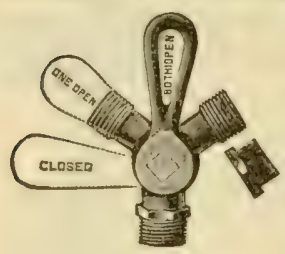

Fig. 1186 is to be used with any of our larger Spray Pumps, where one or two leads of hose are to be employed. Either or both of the discharges may be opened or closed at will as shown in the illustration. Butt threaded to fit Pump. LaterFig. $1 x 86$. als threaded to fit $1 / 2$ inch or $3 / 4$ inch hose coupling.

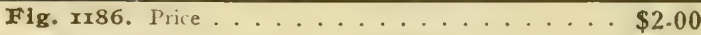

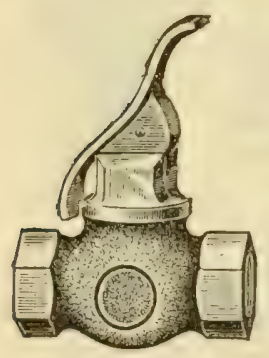

Fig. 1338. Brass stop cock closes by spring pressure and needs only the touch of hand or finger to open or close it. Can be operated by one hand while pumping with the other.

Fig. $x_{33} 8$. Price. . . . $\$ 1.75$

Fig. $133^{8}$.

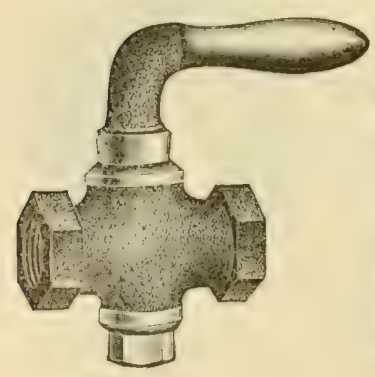

Fig. 54. Stop cock has $1 / 4$ inch female pipe thread cut on both ends.

Fig. 54. Price. . . \$0.65

Fig. 54. 


\section{Goulds Spray Fittings.}

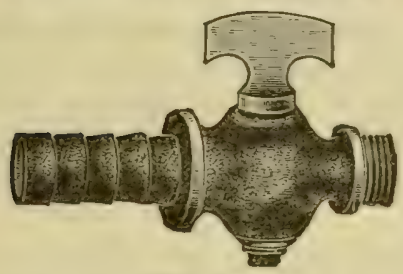

Fig. 85 .

Fig. 85. Brass stop cock with shank for wiring in $1 / 2$ inch hose. Other end cut inch male pipe thread to attach to spray nozzles or pipe extension.

Fig. 85 , Price. . . . . . . . . . . . . . . $\$ 0.65$

Funnel and Strainer.

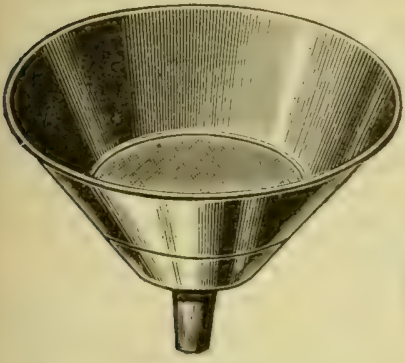

An indispensible piece of apparatus for straining the spraying mixtures into barrel or tank. Made of copper, with brass wire cloth strainer.

Price, to inch diameter. $\$ 2.50$.

Fig. I273.

\section{Sherman Hose Clamps.}

A screwdriver does the business.

\begin{tabular}{|c|c|c|c|c|}
\hline Size, inches. & $\pi / 2$ & $3 / 4$ & I & $x^{2} / 6$ \\
\hline Price per doz. & $\$ 0.6 \overline{0}$ & $\$ 0.60$ & $\$ 2.00$ & $\$ 2.50$ \\
\hline
\end{tabular}

Brass Hose Couplings.

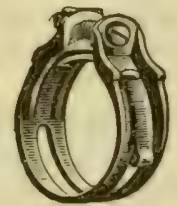

Fig. 1272 .

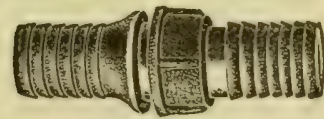

Fig. 504 .

\begin{tabular}{|c|c|c|c|c|c|c|c|}
\hline Size, inches. & $3 / 8$ & $1 / 2$ & $3 / 4$ & I & $I 1 / 4$ & $I^{1 / 2}$ & 2 \\
\hline Price per doz. & $\$ 2.50$ & 3.00 & 3.00 & 4.50 & 10.00 & 14.00 & 30.00 \\
\hline
\end{tabular}

Rubber Spray Hose.

\begin{tabular}{|c|c|c|c|c|}
\hline $\begin{array}{c}\text { Internal } \\
\text { Diameter. }\end{array}$ & $\begin{array}{l}2-\mathrm{Ply}, \\
\text { price per } \mathrm{ft} \text {. }\end{array}$ & $\begin{array}{l}\text { 3-Ply, } \\
\text { price per ft. }\end{array}$ & $\begin{array}{l}\text { 4-Ply, } \\
\text { price per ft. }\end{array}$ & $\begin{array}{l}5-\mathrm{Ply} \text {, } \\
\text { price per } \mathrm{t} t \text {. }\end{array}$ \\
\hline $\begin{array}{ll}3 / 8 & \text { in } \\
1 / 2 & 6 \\
3 / 4 & 6 \\
1 & 16 \\
11 / 4 & 6 \\
11 / 2 & \text { " }\end{array}$ & $\begin{array}{r}\$ 0.20 \\
.20 \\
.25 \\
.33 \\
.42 \\
.50\end{array}$ & $\begin{array}{r}\text { \$. } 25 \\
.25 \\
.30 \\
.40 \\
.50 \\
.60\end{array}$ & $\begin{array}{r}\$ 0.30 \\
.30 \\
.37 \\
.50 \\
.02 \\
.75\end{array}$ & $\begin{array}{c}\$ 0.37 \\
.37 \\
.4^{*} \\
.02^{*} \\
.77^{*} \\
.93\end{array}$ \\
\hline
\end{tabular}

* Used as suction hose. 


\section{Spray Calendar.}

Revised Dec. 15, 1903 and approved by Agricultural Experiment Stations.

The directions in parenthesis are least important, and may be omitted when the trouble has not beenserious or has been checked by previous spraying. Be prompt, thorough and persistent. Practical men have found that it pays to spray every season, whether the disease is prevalent or not

\section{APPLE.}

Siab. I. Copper Sulphate (a) or Bordeaux, when buds are swelling. 2. Bordeaux just before flower buds open. 3 . Repeat 2 when blossoms have fallen. 4. Repeat 3 ten days later. 5. The same after two weeks. Canker worm. I. Arsenites, when caterpillars first appear. 2. If necessary repeat $\mathrm{I}$ after eight to ten days. 3. The same. Bud moth. 1. Arsenites, with the opening of the buds. Combine with I the treatment for Sazb. Colling Moth. I. Arsenites, immediately after the blossoms have fallen. 2. Repeat I seven to ten days later. 3. Repeat 2 in two weeks, if the late broods are troublesome. Combine with spraying for Saab. Case-burer. As for Bud Moth. San José Sale. I. A $20 \%$ kerosene and water mixture, when leaves drop in fall. 2. Repeat I before leaves appear in spring. 3. Repeat I in June, when the first brood comes out. Use kerosene sprays only on a sunny or breezy day. Crude petroleum $25 \%$ in winter while plants are dormant or Lime-Sulphur-Salt early in the spring before buds open. As soon as dry go over again and cover all bare places.

\section{ASPARAGUS.}

Rust. I. Resin-Bordeaux Mixture after cutting season is over, when new shoots are one foot high. 2. Repeat I once a week until Sept. Ist. 3. Repeat I three times after Sept. ist at intervals of ten days. On Seedling plants and beds too young to cut, spraying should begin when plants are a few inches high.

\section{BEAN.}

Anthracnose Pod-rust. I. Bordeaux when first true leaf has expanded. 2. Repeat I ten days later. 3. Repeat I after blossoming. 4, 5, etc. The same at short intervals. Sort the seed, rejecting all that show disease, and soak in a strong ammoniacal solution of Copper Carbonate for half an hour.

\section{BEE'T.}

Leaf spot. I. Bordeaux, when plants are six inches high. 2, 3. Repeat 1. Root-rot. (Sugar beet.) Apply 60 to 70 bushels of lime per acre.

\section{CABBAGE AND CAULIFLOWER.}

Aphis. I. A $5 \%$ kerosene and water mixture, on young plants. 2. Repeat when necessary. Worm and Looper(Plusia). I. Pyrethrum or arsenites if the plants are nut heading; the arsenites preferably in the resin-lime mixture to make them stick. 2. Repeat 1 at intervals of seven to ten days, if necessary. 3. Hellebore, if plants.are heading.

\section{CELERY.}

Rust. I. Keep young plants covered with Bordeaux before transplanting to field. 2, 3 and 4. Repeat I every two weeks. 


\section{CHERRY.}

Black-knot, Rot, and Shot-hole Fungus, see Plum. Aphis. I. I0\% kerosene and water mixture, when insects appear. $(2,3$, etc. Repeat I every four days if necessary.) Slug. 1. Arsenites, hellebore or airslaked lime, when insects appear. $(2,3$. Repeat in ten to fourteen days.) Curculio. Spray with arsenate of lead, 3 lbs. to 100 gals, water, 2 or 3 applications as fruit ripens.

\section{CUCUMBER AND SQUASH.}

Dozmy Mildeze. If for a late crop, Bordeaux, every ten days from the time the plants appear. Striped Cucumber Beetle. Keep plants well covered with Bordeaux when young. This does not kill the Beetles, but keeps them off. Squash bug. Trap under shingles or boards and spray with $5 \%$ kerosene and water in the morning.

\section{CURRANT.}

Anthracnose and Leaf Spot. I. Bordeaux, when the fruit is half grown. 2. Ammoniacal Carbonate of Copper, before fruit is picked. 3. Bordeaux after fruit is picked. (4. Repeat 3, two weeks later.) Worm. I. Arsenites, when first worms appear. 2 and 3 . Repeat I if necessary. 4. Hellebore, after fruit is half grown. Sinn José Siale. See under Afple. Cane-blight. Go over the patch three or four times during the summer, and cut out and burn affected canes. Cut well below the point of disease.

\section{FIELD CROPS.}

Wild Mustard in oats, peas, and other field crops. Solution copper sulphate, (10 pounds to 30 gallons water) when mustard is young and has 4 to 6 leaves.

\section{GOOSEBERRY.}

Mildew. I. Potassium Sulphide, or Bordeaux, as the leaves unfold. 2,3 and 4 . Repeat I every two weeks. Leaf-blight and Worm. See Currant.

\section{GRAPE.}

Anthracnose. I. Iron Sulphate and Sulphuric Acid Solution, before buds break in spring. 2. Kepeat I after three days. If spraying for Rot, further treatment is unnecessary. If not, two or three applications of Bordeaux will be beneficial. Black Rot. I. Bordeaux just before blooming. 2. Kepeat $\mathrm{I}$ after fruit is set, every two weeks. 3. Ammoniacal Copper Carbonate, every seven to fourteen days, after the fruit is half grown. Downy Mildew, Powidery Alildew, Ripe Rot. Controlled by spraying for Rot. Steely-hug. I. Arsenites as buds are swelling. 2. Repeat I after ten to fourteen days. Flea-bectle. I. Paris Gireen or other arsenites at same strength, just before the buds swell. 2. Paris Green when worms appear on leaves. Fidia (Root. Worm) arsenate of lead on leaves, also thorough tillage.

Leaf Hoppers. Whale oil soap for young, $5 \%$ kerosene for adults.

\section{MELONS.}

Dozuny Milder, Striped Beetle. See Cucumber. Louse. A 5 or $10 \%$ kerosene and water mixture, every ten days till the pest is checked.

\section{NURSERY STOCK.}

Fungous diseases, (especially the Leaf-blight of pear seedlings). I. Bordeaux, when leaves appear. 2, 3, etc. Repeat $I$ at intervals of ten to fourteen days. 


\section{PEA.}

Mildeze. If for a late crop, Bordeaux every two weeks. It is unnecessary to spray the early crop.

\section{PEACH, NECTARINE, APRICOT.}

Note.-Afier peach leaves have developed never use Bordeaux stronger than two lbs. Copper Sulphate to a bbl of water and use large excess of lime, as peach foliage is particularly telicate.

Brown Rot. See Plum. Leaf Curl. I. Bordeaux in March. 2. Bordeaux just before the buds open. 3. Repeat one after blossoms fall. Prevented by application of Lime-Sulphur-Salt for San José Scale. Black Spot. Controlled by the application of Bordeaux for Curl, and two subsequent sprayings with this wash. Curculio. See Plum. San José Scale. See Apple.

\section{PEAR.}

Blicht. Cut out and burn all diseased parts as soon as noticed. Cut six to ten inches below the affected part. Leafblight. Frait Spot. Leaf Spot. I. Bordeaux before blossoms open. 2. Repeat I after blossoms fall. 3. The same, two weeks later. If further applications are necessary, use Ammoniacal Carbonate, as Bordeaux will tarnish the fruit. Scap. See Apple, Leaf Blister. I. I5 or $20 \%$ kerosene and water, before buds swell in spring. Psylla. I. A 5 or IC\% kerosene and water mixture when first leaves unfold; or whale-oil soap, one lb. to ten gallons of water. 2,3 , etc. Repeat I at intervals of two to six days. Shug. See under Cherry. San José Scale. Coulling Moth. See under Apple.

\section{PLOM.}

Note.-After the leaves of Japan Plums have developed never use Bordeaux stronger than 2 lbs. Copper Sulphate to a bbl. of water and use large excess of lime as foluage of Japan Plums is particularly delicate.

Brown Kot. I. Copper Sulphate solution (a), before buds swell in spring. 2. Bordeaux when fruit is set. 3 . Repeat 2 after ten to fourteen days. 4. Ammoniacal Copper Carbonate, when fruit is two-thirds grown. 6, 7. Repeat 5 at intervals of five to seven days, if the weather is humid. Gather and burn all mummied fruit on the trees in early spring and that diseased through the summer. Thin fruit to four inches apart. Leaf-blight. Shot-hole Fungus. Controlled by applications $2-5$ for Rot. Black Knot. I. Bordeaux, during the first warm days of early spring. 2. Repeat I when buds are swelling. 3 and 4. Repeat I the last of May and the middle of June. Combine with spraying for Rot. Cut out and burn diseased parts whenever they are seen, and paint wounds with linseed oil. Clear away wild plums and cherries near the orchard. Curculio. Try arsenate of lead. Spraying is not generally successful. Jar trees for two or three weeks after fruit is set, at intervals of one to three days. Gather and burn all stung fruit. P.lum Scale. I. $25 \%$ kerosene and water, in autumn after the leaves have fallen. 2 and 3. Repeat I in spring, before the buds open. San José Scale. See under Apple.

\section{POTATO.}

Early Blight. I. Bordeaux, when vines are six to eight inches high. 2 and 3 . Repeat $\mathbf{I}$ at intervals of two to three weeks. (Only partially successful.) Late Blight. I, 2, 3 . Bordeaux, as for Early Biight. 4, 5. Repeat every two 
weeks. Srab. Soak uncut seed potatoes two hours in solution of Formalia (I pint to 30 gallons of water). Potato Bug. and Flca Beetle. Arsenites, when the beetles or slugs first appear. 2 and 3 . Repeat $I$ if necessary. Use the poison in Bordeaux, if spraying for Blight.

\section{QUINCE.}

Leaf-blight. Fruit Spot. See under Pear. Curculio. See under Plum. San José Scale. See under Apple.

\section{RASPBERRY, BLACKBERRY,DEWBERRY.}

Anthracnose. I. Copper Sulphate Solution. (a) before buds break. 2. Bordeaux, when the young canes are six to ten inches high. 3,4 . Repeat 2 at intervals of one to three weeks. Use Ammoniacal Carbonate or Copper Sulphate (b) when the fruit begins to ripen. Keep spray from the foliage of bearing plants as much as possible.

Orange Rust. Dig up and burn diseased plants when found. Worm. As under Currant.

\section{Formulas.}

\section{FUNGICIDES.}

(For Rots, Blights, Mildews and other Fungous Diseases.)

\section{BORDEAUX MIXTURE.}

Copper Sulphate (Blue Vitriol).....6 6 lbs.

Quick or Stone Lime........... 4 lbs.

Water ..................... 45-50 gals.

Dissolve the Copper Sulphate in an earthen or wooden vessel with three gallons of hot water; or, preferably, put it in a coarse sack, as buriap or cheese cloth, and hang this in 4 to 6 gallons of water near the surface. When dissolved pour into the spraying barrel, and fill the barrel about half full of water. Slake the lime, dilute it to io to 15 gallons, and pour this milk of lime into the barrel through a wire strainer. (SEe Fig. I273, PAGE 33.) Do not mix the Copper Sulphate and lime when less dilute than this, as the resulting Bordeaux is likely to be lumpy, will settle quickly, and is more liable to burn the foliage. Add water to fill the barrel and stir the mixture well for a few minutes. Agitate frequently while it is being applied.

If spraying peaches or Japan plums, use 2 pounds of Copper Sulphate instead of 6 , and add an excess of lime. Bordeaux will adhere better to such smooth-surface plants as cabbage and cauliflower, if about I pound of hard soap dissolved in hot water is added. The mixture itself should always be made fresh for each application, but a stock solution of lime and Copper Sulphate may be kept separately and will be good economy when the spraying operations are extensive.

A stock solution of Copper Sulphate sufficient for a day's spraying in most cases may be made by dissolving $36 \mathrm{lbs}$. of Blue Vitriol in 36 gals. of water. For each barrel of Bordeaux use 2 or 6 gals. of this solution, according to the plants to be sprayed. Keep this stock solution tightly covered to prevent evaporation. In the same way $36 \mathrm{lbs}$. of quick lime may be slaked in as many gallons of water, and used as the copper solution; or it may be slaked with just enough water to make a putty, which will keep indefinitely if covered with water, and is to be used with the ferro-cyanide 
test. If the lime in the Bordeaux mixture is deficient, a drop of a saturated solution of ferro-cyanide of potassium, added to the mixture will turn brown. Add lime till the drop remains colorless and the mixture is ready to use.

\section{COPPER SULPHATE SOLUTION.}

Strength $a$.

Copper sulphate (Blue Vitriol)........ I lb.

Water..................... I I $5^{-2} 5$ gals.

Dissolve the Copper Sulphate in water when ready for use ; or take a gallon of the stock solution. (See Bordeaux Mixture.) This strength is to be used only before the buds break. It should never be applied to foliage. For peaches and Japan plums use 25 gals. of water.

Strength $b$.

Copper Sulphate (Blue Vitriol)....... I lb.

Water ...................... 200-300 gals. This solution is gaining ground as a substitute for the Ammoniacal ('arbonate of Copper in spraying ripening fruits, especially plums. At the rate of $1 / 4 \mathrm{lb}$. per bl)l. it is equally effective and seldom in jures the foliage appreciably, though it is always better to add a little milk of lime. Use the weaker strength given on peaches and Japan plums. It does not stick like Bordeaux, and must be used about twice as often.

\section{AMMONIACAL COPPER CARBONATE.}

Copper Carbonate ............. 5 oz.

Ammonia $\left(26^{\circ}\right.$ Beaume) about........ 3 pints.

Water. .................. 45 450 gals. Make a paste of the Copper Carbonate with a little water and dilute the ammonia with 7 to $S$ volumes of water. Add the diluted ammonia to the paste, but be careful to use only enough to dissolve all the Copper Carbonate. Allow the solution to settle and use only the clear blue liquid. This loses strength on standing in open vessels, but may be kept indefinitely in a stoppered bottle. For spraying dilute to 45 to 50 gallons.

\section{IRON SULPHATE AND SULPHURIC ACID SOLUTION.}

Iron Sulphate (Copperas) ........... I Io lbs.

Sulphuric Acid.................. I quart.

Hot Water ................... 26 gals.

Add the acid to the copperas and pour on the water. Use when fresh. To be used only as a wash before the buds swell, applied with brush or sponge. Its chief value is for grape anthracnose.

\section{POTASSIUM SULPHIDE SOLUTION.}

Potassium Sulphide......... I/2 to I oz.

Water.................... I gal.

This loses strength in standing and should be used immediately. Keep the Sulphide in a stoppered bottle. Valuable for mildews, especially the Gooseberry mildew.

\section{POISON INSECTICIDES OR AR- SENITES.}

(For insects that chew.)

\section{PARIS GREEN.}

Paris Green............. I lb.

Water...................... 150-300 gals.

Quick Lime................ 2 to 3 lbs. 
The usual strength for summer spraying is $1 / 4 \mathrm{lb}$. per bar rel (about 45 gallons). Lime should always be added to a Paris Green mixture to avoid burning the foliage. Peaches and Japan Plums are most liable to injury. Stir the mixture frequently when spraying. A common method is to apply the Paris Green in Bordeaux ; as for Apple Scab and the Codling moth. The action of neither is weakened, and the Paris Green loses all its caustic properties.

\section{GREEN ARSENOID, PARAGREEN.}

To be used like Paris Green. They are cheaper, remain longer in suspension, and are equally effective. These insecticides deserve to come into general use.

\section{ARSENITE OF LIME.}

This insecticide is coming more into popular favor yearly, and is worthy of it. Arsenite of lime is at least one-half cheaper than Paris Green, is equally efficient, and will not burn the tenderest foliage at the strength ordinarily applied. To make 800 gallons of spraying mixture:

White Arsenic................. lbs.

Sal Soda....................... 8 lbs.

Water ....................... gals.

Boil all together for 15 minutes, or till the arsenite dissolves. One pint of this stock solution, and $2 \mathrm{lbs}$. of slaked lime, added to a barrel of water is equal in insecticidal value to $1 / 4 \mathrm{lb}$. of Paris Green, and costs half as much. Arsenite of lime ought to be used more generally in place of Paris Green.

ARSENATE OF IEAD. For insects that chew.

I to 5 lbs. per 100 gals. It does not burn the foliage.

\section{WHITE HELLEBORE AND PYRETHRUM.}

Preferably in water, $\mathrm{I}$ oz. to 3 gals.; or dry, mixed with 1/4 part of flour to make it adhesive. Hellebore and Pyrethrum are used chiefly on ripening fruit, as they lose their poisonous properties when exposed to the air for a few hours.

\section{RESIN LIME MIXTURE.}

In spraying for chewing insects on plants with smooth leaves, as cabbage and cauliflower, it is difficult to make the poison adhere. This may be overcome by using the arsenites in the following material :

Pulverized Resin.............. 5 lbs.

Concentrated Lye............... I l lb.

Fish Oil (or other animal oil, except tallow) .................. I pint.

Water................... 5 gals.

Heat oil and resin with a gallon of water till the resin is softened. Add lye and the remaining 4 gallons of water and boil about two hours, or till the mixture will unite with cold water. Add water to make 5 gallons of this stock solution. When needed for spraying take

Resin mixture .............. r gal.

Whitewash............... 3 gals.

Paris Green..............

Water.................. 16 gals. 


\section{CONTACT INSECTICIDES.}

(For sucking insects and San José Scale.)

\section{REROSENE AND WATER MIXTURE.}

This may be used in any case where Kerosene Emulsion or whale oil soap has been recommended in the past. It is more economical than the emulsion, and is easier to apply. GOULDS "KEROWATERS" (pages I7 to 20) provide for making and applying any desired strength. For scale insects use a $15 \%$ to $25 \%$ mixture; $5 \%$ strength is strong enough for such insects as mealy bugs, plant lice and thrips. Cabbage worms, currant worms and other soft-bodied insects may also be treated successfully.

\section{TOBACCO WATER.}

Boil stems and strain liquid. Add water to make 2 gallons of liquid to each pound of stems used. For soft-bodied insects. The efficiency of Tobacco Water will be increased by stirring in I pound of whale oil soap to each 50 gallons.

\section{IIME-SULPHUR-SALT.}

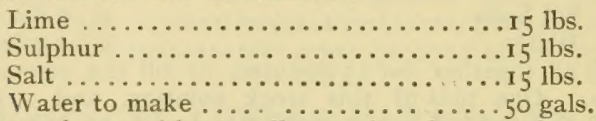

Boil two hours with a small quantity of water then dilute to 50 gals. with boiling water. Do not let mixture become cold, spray while yet warm. For winter or early spring use.

\section{FROM ONE WHO KNOWS.}

The Goulds Mfg. Co.

Gassport, N. Y., December 17, '03.

\section{Dear Sirs :}

$$
\text { Seneca Falls, N. Y. }
$$

During the past season I have used your Power Spraying Outfit with the greatest success. Cannot speak too highly of it. The engine is simple and easily operated and the Pump is far ahead of anything $I$ have seen. You have the acme of perfection in your idea of three upright plungers, which insures a smooth flow of water without change of pressure, and obliterates all the back-lash on the engine, which is the common fault in other styles of Pumps I have seen.

$$
\text { (Signed) M. O. MesLer. }
$$



LIBRARY OF CONGRESS

|||||||||||||||| ||||||||||||||||||||||||||

0000890599 A 